ECCOMAS Proceedia
COMPDYN 2021

$8^{\text {th }}$ ECCOMAS Thematic Conference on Computational Methods in Structural Dynamics and Earthquake Engineering M. Papadrakakis, M. Fragiadakis (eds.) Streamed from Athens, Greece, 28 - 30 June 2021

\title{
EVALUATION OF THE SEISMIC BEHAVIOR OF HISTORICAL CHURCHES REINFORCED BY CROSS-LAM ROOF-STRUCTURE
}

\author{
N. Longarini ${ }^{1}$, P. Crespi ${ }^{2}$, and M. Zucca ${ }^{2}$ \\ ${ }^{1}$ Department of Architecture, Built Environment and Construction Engineering, Politecnico di Milano \\ e-mail: nicola.longarini@polimi.it \\ ${ }^{2}$ Department of Architecture, Built Environment and Construction Engineering, Politecnico di Milano \\ \{pietro.crespi,marco.zucca\}@polimi.it
}

\begin{abstract}
Many typical historical masonry churches, with one nave and wooden roofs, have shown high seismic vulnerability in the recent seismic events, especially under transverse earthquakes. In fact, the nave transverse response of this kind of constructions is influenced both by the materials features and the geometrical characteristics. In order to improve the seismic response, the box behavior strategy basing on dissipative roof-diaphragm, can be pursued by adopting cross laminated timber panels (CLT). In this paper, for five historical masonry churches, the effectiveness of different CLT panels solutions is investigated by performing comparative nonlinear dynamic analyses adopting equivalent finite element models. The CLT solutions differ themselves for the panels thickness $(6 \mathrm{~mm}$ and $10 \mathrm{~mm})$ and the number of the connections $(8$, 16 and 32 crews in one linear meter). The results are shown in terms of dimensionless transverse displacement (drift) and shear occurred at the base of the façade. Therefore, the influence of the most important geometrical features (as slenderness of the perimeter walls, the width and the length of the churches) in the seismic response is pointed out for each church equipped by different CLT roof-diaphragm solutions.
\end{abstract}

Keywords: Historical Churches, Seismic Vulnerability, Roof-Diaphragm, Time-History analysis.

ISSN:2623-3347 @ 2021 The Authors. Published by Eccomas Proceedia. Peer-review under responsibility of the organizing committee of COMPDYN 2021. doi: $10.7712 / 120121.8781 .18719$ 


\section{INTRODUCTION}

In the historical masonry churches the observation of post-earthquake damages allowed the identification of several recurring collapse mechanisms $[1,2,3]$. In the nave transversal response [4] an excessive rocking of the perimeter walls can lead to: (i) out-of-plane mechanisms with a consequent collapse of the roof structure supports $[5,6,7]$ or (ii) in-plane excessive stress in the walls in parallel located with respect to the earthquake. On the other hand, the historical masonry churches with wooden roof structures, realized in several configurations in according to the traditional construction techniques of the location site $[8,9]$, were originally designed to withstand static loads even if the constructions are in regions nowadays classified as seismic [10-15]. To preserve the cultural heritage, the seismic strengthening of historical churches represents a mandatory issue achieving by retrofitting strategies able to provide the "global box behavior" to the construction. Therefore, after accurate analyses about (i) the conservation status of the masonry and wooden elements, (ii) the clamping between the head and perimeter walls and (iii) the wall-to-roof connections, the retrofitting operations can be chosen in order to avoid both out-of-plane and in-plane collapse mechanisms.

Comparative analyses among churches with same configuration can be useful to predict the structural failure in seismic response and to orient the retrofitting techniques [16-20] according to the conservative restoration criteria satisfying, as far as possible, the original material compatibility without changing the authenticity of the constructions [21, 22, 23]. Among these techniques the realization of dissipative wooden based roof-diaphragm represents a valid option because the out-of-plane rocking of the longitudinal walls can be reduced limiting the in-plane shear actions transferred to the head walls [24]. Several wooden based roofdiaphragm configurations can be realized $[25,26,27]$. One of these is based on the use of Cross Laminated Timber (CLT) panels characterized by an alternated sequence of glued timber layers $[28,29,30]$. This kind of panels have been initially adopted in new timber buildings [31-34] but, in several experimental tests and numerical analyses, they have shown enough in-plane stiffness able to guarantee the floor diaphragm effect especially if the panels are over-placed on the existing wooden beams or planks creating wood-to-wood composite sections $[35,36,37]$. Under the seismic actions, the energy dissipation in the timber roofdiaphragm must be occurred in the panel-to-panel and wall-to-panel connections, as a consequence the roof diaphragm should be designed in terms of strength, stiffness and ductility [13, 38]. In fact, if the connection resistance exceeding the seismic demand an elastic response without energy dissipation can be occurred, vice versa an excessive stiffness can increase the shear in the folded CLT panels with a consequent thickness increase.

Considering the previous issues, the present work is aimed to evaluate the influence of the geometrical and material features on the nave transverse response for different one nave configuration churches, reinforced by CLT roof structures, under the same seismic action. An adequate representation of the non-linear behavior of the masonry and roof-diaphragm (CLT panels with steel connections) is required to investigate the seismic response under the transverse earthquake $[19,39,40]$. In this way, several methods with different level of accuracy and computational costs should be considered [41], e.g. simplified method [42], limit analysis [43], macro-modelling based on finite element method [44] and equivalent models [25]. These methods are generally based on the discretization of the structure by macro-elements, with concentrated non-linear properties. In the present work, the macro-elements approach is used by equivalent models implementation with vertical mono-dimensional elements representing the masonry elements and horizontal ones representing the roof diaphragm [45]. Nonlinear dynamic analyses are performed by introducing the seismic action as time histories in order to simulate the damped rocking mechanism pursued by the dissipative roof-diaphragm. 


\section{EQUIVALENT MODEL}

The non-linear dynamic analyses have been performed considering an equivalent finite element model where the structural elements involve in the seismic response of the church are schematized with mono-dimensional macro-elements. In fact, the church was subdivided into n-seismic resistant systems transversally disposed with respect to the nave: façade, lateral walls coupled themselves, triumphal arches and head wall (Figure 1). The non-linear properties of the perimeter masonry walls and the CLT roof diaphragm are assigned to the related equivalent elements according to [25].

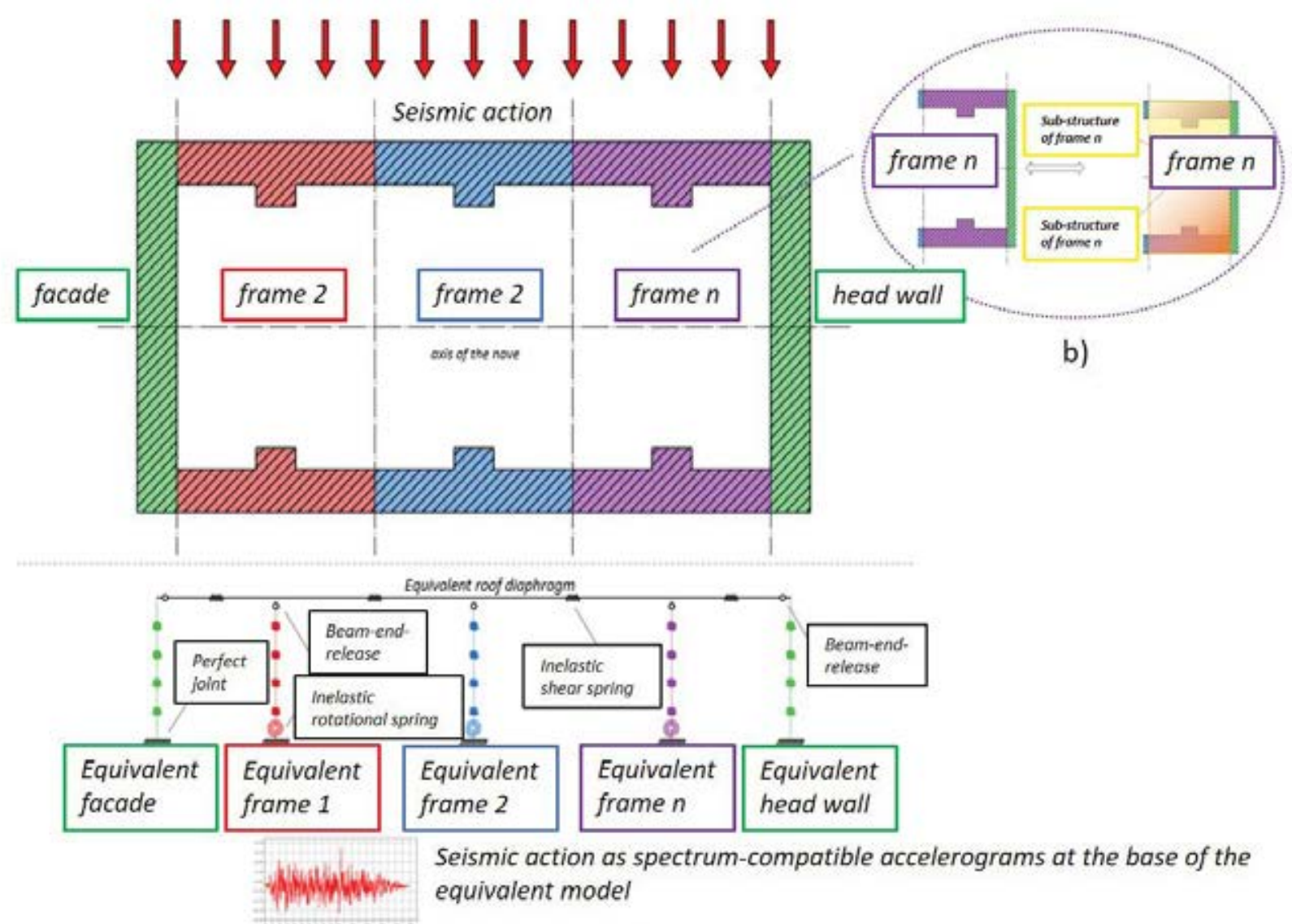

a)

Figure 1: a) Identification of seismic resistant frame in the one nave configuration church (plan view) and related equivalent finite element model representation (longitudinal view) and b) plan view of the sub-structures characterizing the n-seismic resistant frame.

To implement the equivalent finite element model, three main steps are considered. In the first step, pushover analyses are performed considering the sub-structures schematizing the single parts of the n-seismic resistant systems as the piers of the longitudinal walls included within the openings or the abutments (Figure 1 and 2a). Each sub-structure is subdivided in section with fibers discretization where the non-linear characteristics are calculated considering a trilinear constitutive law with tensile strength equal to 0 or concrete damaged elasticity model $[46,47]$ in which tensile cracking and compressive crushing as main failure modes.

In the second step, the yielding and ultimate values obtained by the M- $\chi$ diagrams calculated through the pushover analyses performed in the first step, are used to implement the inelastic rotational springs assigned at the base of the seismic resistant elements considering a bilinear constitutive low. Pushover analyses are again carried out in order to obtain the base 
shear-top displacement $(\mathrm{V}-\delta)$ curves of the transversal resistant system and the M- $\chi$ which characterizes each system is evaluated considering the related shear length (Figure $2 b$ ).

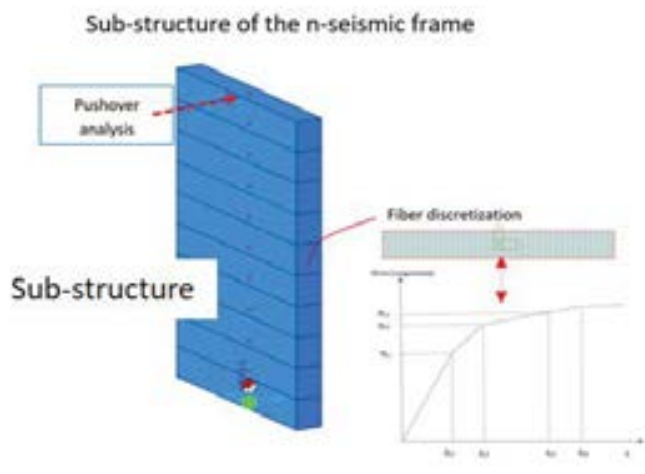

a) from pushover analysis $\rightarrow(M-x)_{\text {wat strutiver }}$

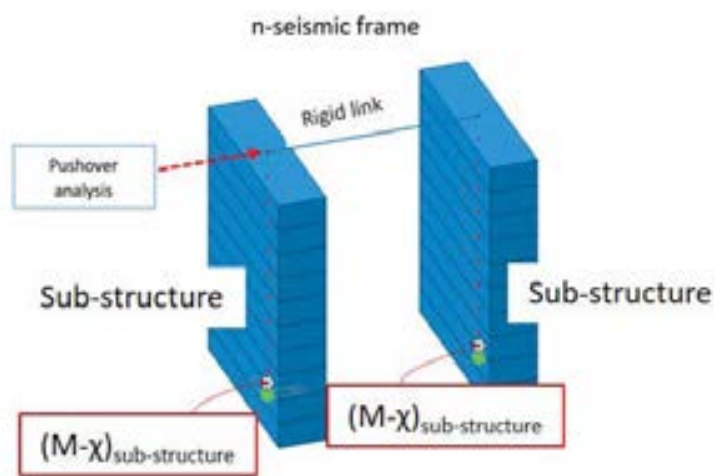

b) from pushover analysis $\rightarrow(\mathrm{M}-\mathrm{x})_{-}$trame

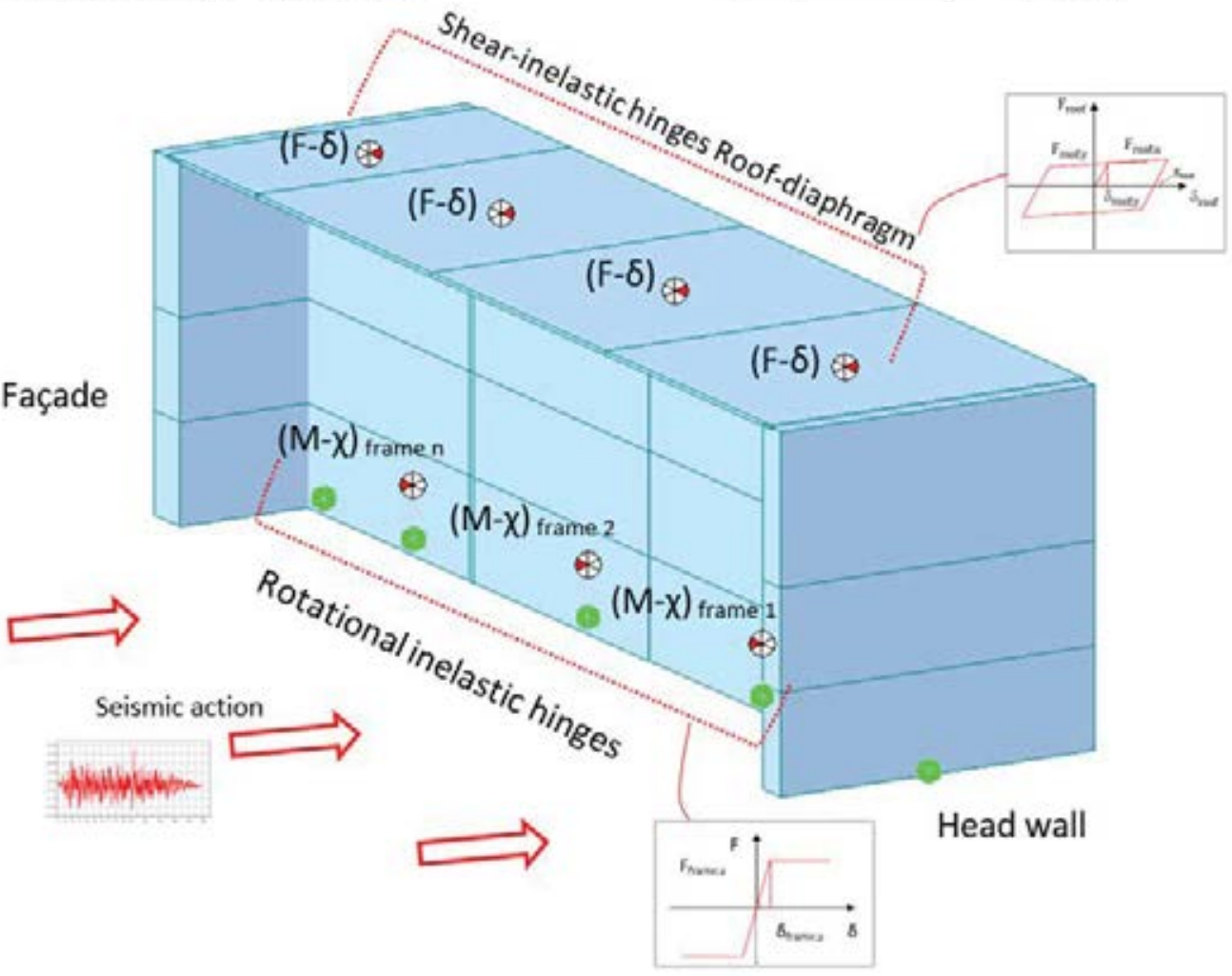

c) equivalent finite element model (EQ FEM)

Figure 2: a) pushover analyses on sub-structures, b) pushover analyses on seismic resistant frame with inelastic rotational springs having $\mathrm{M}-\chi$ detected in step a) and c) equivalent finite element model under seven spectrumcompatible accelerograms.

In the third step, the head wall, the façade and the transversal frames are schematized through mono-dimensional equivalent elements. Furthermore, the façade and the head wall are implemented by equivalent elastic mono-dimensional elements fully restrained at the base, considering that their in-plane strength and stiffness are greater than the longitudinal walls [25, 48]. The transversal frames are characterized by the presence of concentrated inelastic rotational springs located at the base and obtained from the above-mentioned $\mathrm{M}-\chi$ diagrams calculated during the second step (Figure 2c). The equivalent finite element model (EQ_FEM) is 
completed through the application of horizontal mono-dimensional equivalent elements representing the roof-diaphragm. The elements of the roof are linked to the vertical ones by hinges located at the end of the vertical elements in order to trigger the rocking and it allows to not transfer the bending moment to the roof. The equivalent elements of the roof are also pinned with respect to the head wall and façade. The shear deformability that characterizes the roof and the non-linear behavior of the connections are implemented to consider the dissipative response of the roof diaphragm through elasto-plastic shear hinges. The shear roof springs are implemented considering a trilinear degrading model [49] or Clough model [28, 50, 51] where the unloading stiffness is calculated considering the reduction of the elastic one with the following relation:

$$
K_{R}=K_{0}\left|D_{y} / D_{m}\right|^{\alpha} \leq K_{0}
$$

where $K_{R}$ is the unloading stiffness, $K_{0}$ is the elastic stiffness, $D_{y}$ is the yield displacement, $D_{m}$ is the maximum displacement and $\alpha$ is the unloading stiffness degradation parameter, in this case equal to 0.4 . The unloading stiffness gradually reduces when the deformation increases. The seismic action is applied considering a set of spectrum-compatible accelerograms acting transversely to the nave.

\section{DAMPED ROCKING RESPONSE}

The CLT panels, the wall-to-roof and wall-to-wall connections represent a deformable diaphragm which allow the rocking trigger of the perimeter walls but limiting either the drift in a fixed design range and the seismic loads on the rigid head walls (thanks to the energy dissipation occurred in the steel connections). The dissipative roof-diaphragm represents a damper located at the top of the constructions with a behavior analogous to one of a top located damper [4]. By the dissipative roof-diaphragm, the nave transverse response of one nave historical church, usually characterized by high percentage of the total mass involved in the first vibrational mode, can be represented by flag-shaped diagram (Figure 3c) obtained from the bi-linear free rocking behavior of the masonry seismic resistant systems (Figure 3a) [45] and the (ii) the dissipative hysteretic behavior of the roof-diaphragm (Figure 3b) [52, 53].

It is possible to represent the bi-linear behavior of the free rocking through the yielding $\left(F_{\text {frame,y }}\right)$ and ultimate $\left(F_{\text {frame,u }}\right)$ force related to the yielding $\left(\delta_{\text {frame,y }}\right)$ and ultimate $\left(\delta_{\text {frame,u }}\right)$ displacement of the generic resistant seismic frame, obtained by the pushover analyses performed during the second step and mentioned in Section 2. The frame stiffness is calculated considering the following relation:

$$
\mathrm{k}_{\text {frame }}=\mathrm{F}_{\text {frame,y }} / \delta_{\text {frame,y }}
$$

Furthermore, it is possible to schematize the dissipative behavior of the roof considering the yielding $\left(\mathrm{F}_{\text {roof,y }}\right)$ and ultimate $\left(\mathrm{F}_{\text {roof,u }}\right)$ force related to the yielding $\left(\delta_{\text {roof,y }}\right)$ and ultimate $\left(\delta_{\text {roof,u }}\right)$ displacement that characterizes the roof. These values are obtained by the experimental tests on the connector chosen for the connections [28, 54]. Similarly, the roof stiffness is evaluated as follow:

$$
\mathrm{k}_{\text {frame }}=\mathrm{F}_{\text {roof,y }} / \delta_{\text {roof,y }}
$$

The flag shaped diagram, shown in Figure 3c, is based on two fundamental hysteretic variables $\zeta$ and $\beta$, defined as follow: 


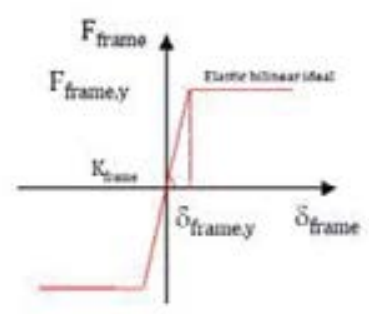

a) Free rocking system

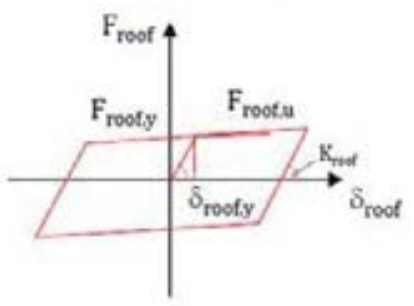

b) Elasto-plastic roof diaphragm

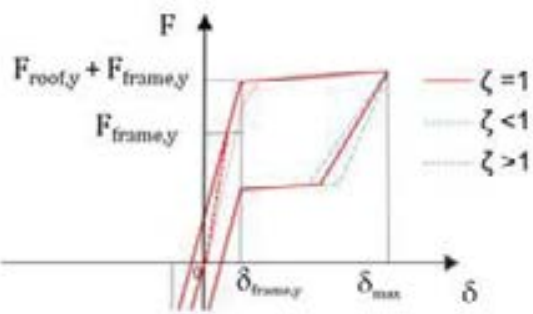

d) Damped rocking when the rocking activation's displacement differs from the roof's yielding displacement

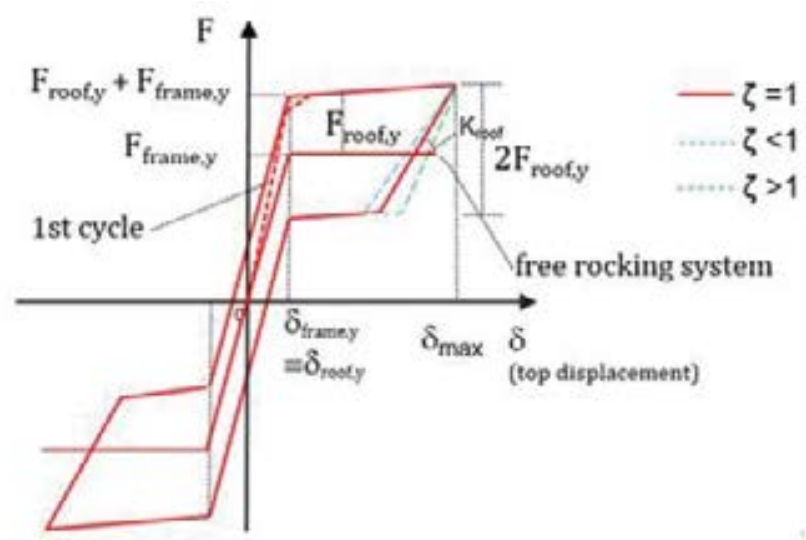

c) Flag shaped diagram of dissipative rocking

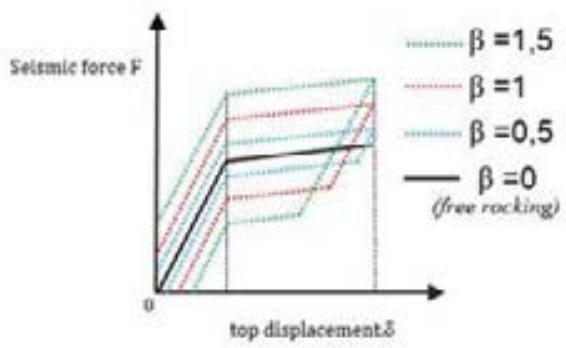

e) Variation of the flag shaped capacity curve for $\beta$ variation

Figure 3: dumped rocking diagram.

$$
\begin{gathered}
\zeta=\left(\mathrm{F}_{\text {roof,y }} \cdot \mathrm{k}_{\text {frame }}\right) /\left(\mathrm{k}_{\text {roof }} \cdot \mathrm{F}_{\text {frame,u }}\right) \\
\beta=2 \mathrm{~F}_{\text {roof,y }} / \mathrm{F}_{\text {frame,y }}
\end{gathered}
$$

It is possible to define the yielding force of the roof in terms of $\beta$ :

$$
\mathrm{F}_{\text {roof,y }}=\left(\mathrm{F}_{\text {frame, }} \cdot \beta\right) / 2
$$

while the roof stiffness can be calculated considering both $\zeta$ and $\beta$ parameters:

$$
\begin{gathered}
\mathrm{k}_{\text {roof,y }}=\left(\mathrm{k}_{\text {frame }} \cdot \mathrm{F}_{\text {roof,y }}\right) /\left(\zeta \cdot \mathrm{F}_{\text {frame,y }}\right) \\
\mathrm{k}_{\text {roof,y }}=\mathrm{k}_{\text {frame,y }} \cdot\left[\left(\beta \cdot \delta_{\text {frame,y })} /\left(2 \cdot \delta_{\text {roof,y }}\right)\right]\right.
\end{gathered}
$$

It possible to notice that $\zeta$ can be described through the ratio between the yielding displacement of the roof and the yielding displacements of the frame $\left(\zeta=\delta_{\text {roof-y }} / \delta_{\text {frame-y }}\right)$ and pro- 
vides a measure of the roof diaphragm. As shown in Figure $3 \mathrm{~d}, \zeta$ is indirectly proportional to $k_{\text {roof }}$ because if $\zeta$ increases, lower energy dissipation occurs.

The $\beta$ parameter is fundamental for the correct intervention design because it is an index of the energy dissipated by the roof: if $\beta$ increases, the damping effect increases (Figure $3 \mathrm{e}$ ). Usually, the $\beta$ value is between 0 and 1.5. In fact, $\beta<2$ is preferable because it allows the selfcentering rocking behavior whereas for $\beta>2$ there-centering functioning is partially inhibited having a flag-shaped diagram with significant residual displacement, as shown in Figure 3e where the diagram changes from blue line to green one.

The roof diaphragm stiffness, related to the wood elements and the steel connections, is evaluated considering the bending stiffness $\mathrm{k}_{\mathrm{df}}$ and the shear stiffness $\mathrm{k}_{\mathrm{dt}}$ :

$$
\mathrm{k}_{\text {roof }}=\left(1 / \mathrm{k}_{\mathrm{df}}-1 / \mathrm{k}_{\mathrm{dt}}\right)^{-1}=\left[(5 / 6) \cdot\left(\mathrm{L}^{3} / \mathrm{E}^{*}{ }_{\mathrm{w}} \cdot \mathrm{J}_{\mathrm{id}}\right) \cdot\left(\chi \mathrm{L} / \mathrm{G}^{*}{ }_{\mathrm{w}} \mathrm{A}^{*}\right)\right]^{-1}
$$

where $\mathrm{E}^{*}{ }_{\mathrm{w}}$ is the equivalent elastic modulus, $\mathrm{G}^{*}{ }_{\mathrm{w}}$ is the equivalent shear modulus and $\mathrm{J}_{\mathrm{id}}$ is the ideal inertia moment of the section:

$$
\begin{gathered}
\mathrm{E}^{*}{ }_{\mathrm{w}}=\left[\left(\mathrm{Lk}_{\mathrm{n}} / \mathrm{n}_{\mathrm{s}}\right) /\left(2 *\left(\left(\mathrm{t}_{\mathrm{w}} \mathrm{L}_{\mathrm{y}} / \cos \alpha\right) / \mathrm{n}_{\mathrm{n}}\right)+\left(\left(\left(\mathrm{k}_{\mathrm{n}}\left(\mathrm{L} / \mathrm{n}_{\mathrm{s}}\right)\right) / \mathrm{E}_{\mathrm{w}}\right)\right]\right.\right. \\
\mathrm{G}^{*}{ }_{\mathrm{w}}\left(\mathrm{n}_{\mathrm{n}}, \mathrm{n}_{\mathrm{s}}\right)=\left[\left(\mathrm{Lk}_{\mathrm{n}} / \mathrm{n}_{\mathrm{s}}\right) /\left(2 *\left(\left(\mathrm{t}_{\mathrm{w}} \mathrm{L}_{\mathrm{y}} / \cos \alpha\right) / \mathrm{n}_{\mathrm{n}}\right)+\left(\left(\left(\mathrm{k}_{\mathrm{n}}\left(\mathrm{L} / \mathrm{n}_{\mathrm{s}}\right)\right) / \mathrm{G}_{\mathrm{w}}\right)\right]\right.\right. \\
\mathrm{J}_{\mathrm{id}}\left(\mathrm{n}_{\mathrm{n}}, \mathrm{n}_{\mathrm{s}}\right)=\left(\mathrm{t}_{\mathrm{w}} \mathrm{L}^{3} \mathrm{y} / 12 \cos \alpha\right)+\mathrm{n}_{\mathrm{ws}} \cdot\left[2 \mathrm{~A}_{\mathrm{s}}\left(\mathrm{L}_{\mathrm{y}} / 2\right)^{2}\right]
\end{gathered}
$$

considering that $\mathrm{n}_{\mathrm{ws}}$ is the homogenization coefficient of the steel connection to the wooden diaphragm ( $\mathrm{n}_{\mathrm{ws}}=\mathrm{E}_{\mathrm{s}} / \mathrm{E}_{\mathrm{w}}{ }^{*}$ where $\mathrm{E}_{\mathrm{S}}$ is the Young modulus of the steel), $\mathrm{L}$ is the distance between the transversal seismic resistant elements and the central nave, $\mathrm{L}_{\mathrm{y}}$ is the roof width, $\mathrm{k}_{\mathrm{n}}$ is the stiffness of the single connector, $t_{\mathrm{w}}$ is the panels thickness, $\mathrm{n}_{\mathrm{s}}$ is the number of the connections stripes for each span, $\mathrm{n}_{\mathrm{n}}$ is the number of connectors for each connections stripe equal to the ratio between the inter-axis of the seismic elements and the inter-axis of the connectors.

The initial value of $\mathrm{k}_{\text {roof }}$ depends on the geometrical characteristics and the material properties of the CLT panels and on the connections details, calculated according to [24, 25]. This value of $\mathrm{k}_{\text {roof }}$ can be used in the non-linear dynamic analyses even if the optimum roof stiffness ( $\mathrm{k}_{\text {roof-opt }}$ ) could be consequently evaluated in correspondence to optimal $\beta$ ( $\beta_{\text {opt }}$ ) able to limit the drift under the design value $\delta_{\text {design }} \leq 0.005 \mathrm{~h}_{\mathrm{w}}$, where $\mathrm{h}_{\mathrm{w}}$ is the height of the perimeter walls [25]. $\mathrm{k}_{\text {roof-opt }}$ is evaluated according to the following relation:

$$
\mathrm{k}_{\text {roof-opt }}=\left(\beta_{\text {opt }} \cdot \mathrm{k}_{\text {frame }}\right) / 2 \Delta
$$

where $\Delta$ is the ratio between the yielding displacement $\left(\delta_{\text {roof,y }}\right)$ of the roof and the yielding displacement of the frame $\left(\delta_{\text {frame,y }}\right)$. The approach is valid because the drift limitation is the first step towards the evaluation of the roof-diaphragm effectiveness. Furthermore, the stiffness of the roof- diaphragm does not influence the intensity of the seismic action on the structure, vice-versa it affects the maximum drift.

\section{CASE STUDIES}

The parametric non-linear dynamic analysis is carried out considering some of the fundamental geometrical features that characterize the five existing one nave historical churches under study (Figure 4) strengthen by four different CLT panels roof structure configurations, 
varying the value of $\beta$ between 0.1 and 1.5. Table 1 shows the values of the geometrical and material characteristics of the above-mentioned churches under study, where $\mathrm{C}$ is the number of spans, $1_{\mathrm{c}}$ is the length of the church, $1_{\mathrm{f}}$ is the width of the church, $t_{\mathrm{w}}$ is the average thickness of the lateral walls, $h_{w}$ is the height of the lateral walls, $\lambda_{w}$ is the geometrical slenderness of the walls given by the ratio $\lambda_{\mathrm{w}}=\mathrm{h}_{\mathrm{w}} / \mathrm{t}_{\mathrm{w}}, \mathrm{h}_{\mathrm{f}}$ is the height of the façade, $\lambda_{\mathrm{f}}$ is the geometrical slenderness of the façade given by the ratio $\lambda_{\mathrm{f}}=\mathrm{h}_{\mathrm{f}} / \mathrm{l}_{\mathrm{f}}, \mathrm{S}_{\mathrm{F}}$ is the shape factor $\left(\mathrm{S}_{\mathrm{F}}=1_{\mathrm{c}} / 1_{\mathrm{f}}\right), \mathrm{E}_{\mathrm{m}}$ is the elastic modulus of the masonry, $G_{m}$ is the shear modulus of the masonry and $\mathrm{w}_{\mathrm{m}}$ is the weight density of the masonry while Figure 5 reports the value of the geometrical characteristics of the churches.

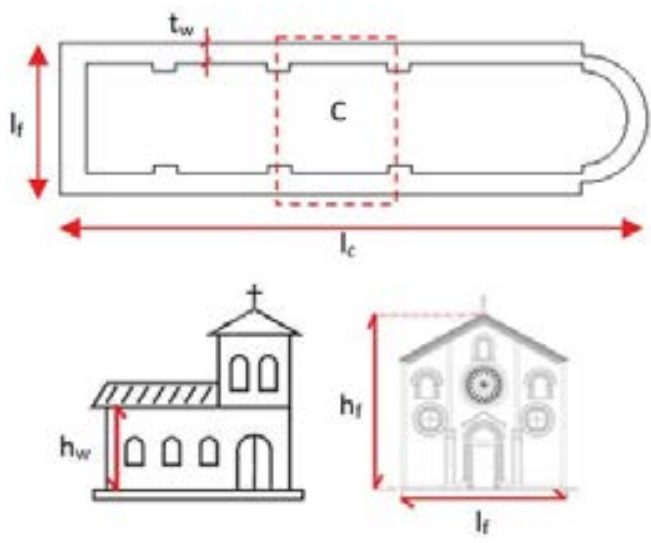

Figure 4: main geometrical characteristics of the churches considered in this work.

\begin{tabular}{cccccccccccc}
\hline church & $\mathbf{C}$ & $\begin{array}{c}\mathbf{l}_{\mathbf{c}} \\
{[\mathbf{m}]}\end{array}$ & $\begin{array}{c}\mathbf{l}_{\mathbf{f}} \\
{[\mathbf{m}]}\end{array}$ & $\begin{array}{c}\mathbf{t}_{\mathbf{w}} \\
{[\mathbf{m}]}\end{array}$ & $\begin{array}{c}\mathbf{h}_{\mathbf{w}} \\
{[\mathbf{m}]}\end{array}$ & $\begin{array}{c}\lambda_{\mathbf{w}} \\
{[-]}\end{array}$ & $\begin{array}{c}\lambda_{\mathbf{f}} \\
{[-]}\end{array}$ & $\begin{array}{c}\mathbf{S}_{\mathbf{F}} \\
{[-]}\end{array}$ & $\begin{array}{c}\mathbf{E}_{\mathbf{m}} \\
{[\mathbf{M P a}]}\end{array}$ & $\begin{array}{c}\mathbf{G}_{\mathbf{m}} \\
{[\mathbf{M P a}]}\end{array}$ & $\begin{array}{c}\mathbf{W} \mathbf{m} \\
{\left[\mathbf{k N} / \mathbf{m}^{3}\right]}\end{array}$ \\
\hline $\begin{array}{c}\text { San Pietro } \\
\text { Felizzano }\end{array}$ & 7 & 25 & 8.50 & 1.35 & 10.7 & 7.92 & 1.25 & 2.94 & 1500 & 500 & 18 \\
$\begin{array}{c}\text { San Pietro } \\
\text { Celestino }\end{array}$ & 4 & 24 & 8.75 & 1.50 & 11.10 & 7.40 & 1.26 & 2.74 & 1230 & 410 & 20 \\
$\begin{array}{c}\text { Santa Maria del } \\
\quad \text { Parco }\end{array}$ & 6 & 33 & 10.00 & 1.50 & 11.75 & 9.79 & 1.18 & 3.30 & 1080 & 360 & 16 \\
$\begin{array}{c}\text { Santa Maria del } \\
\text { Carmelo }\end{array}$ & 5 & 32 & 9.36 & 1.65 & 16.00 & 9.70 & 1.70 & 3.42 & 1230 & 410 & 20 \\
$\begin{array}{c}\text { San Lorenzo } \\
\text { Sarmento }\end{array}$ & 3 & 16 & 4.80 & 1.65 & 5.00 & 7.14 & 1.04 & 3.33 & 1050 & 350 & 18 \\
\hline
\end{tabular}

Table 1: geometrical and material characteristics of the churches under study.

Table 3 summarizes the CLT panels roof structure configurations considered in this study which are characterized by the same type of connectors with $\varnothing 10$ diameter steel screws and stiffness $\mathrm{k}_{\mathrm{c}}=6500 \mathrm{~N} / \mathrm{mm}$ but different panels thickness $(\mathrm{t})$, connectors number in the strips present for each span $\left(n_{s}\right)$ and mutual distance between the connectors (i) (Figure 6). 


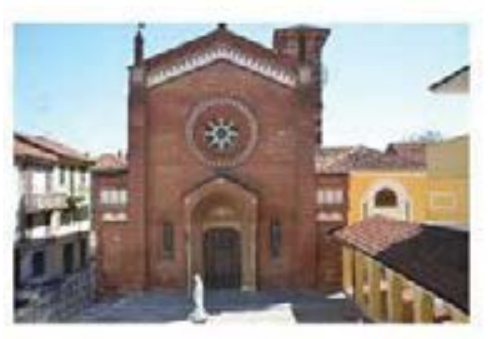

San Pietro (Felizzano)

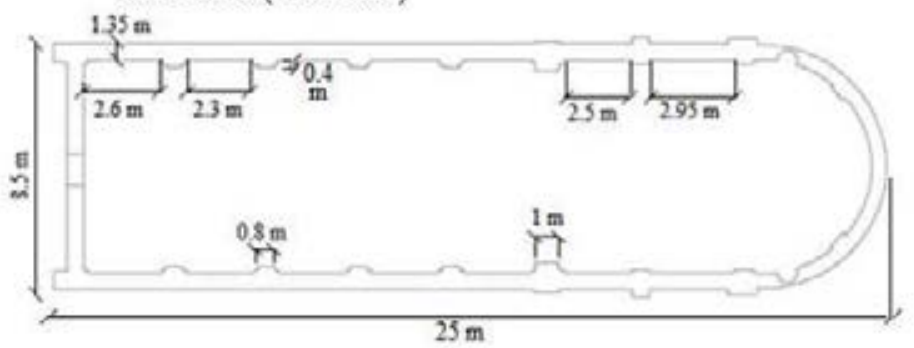

San Pietro Celestino (Isernia)
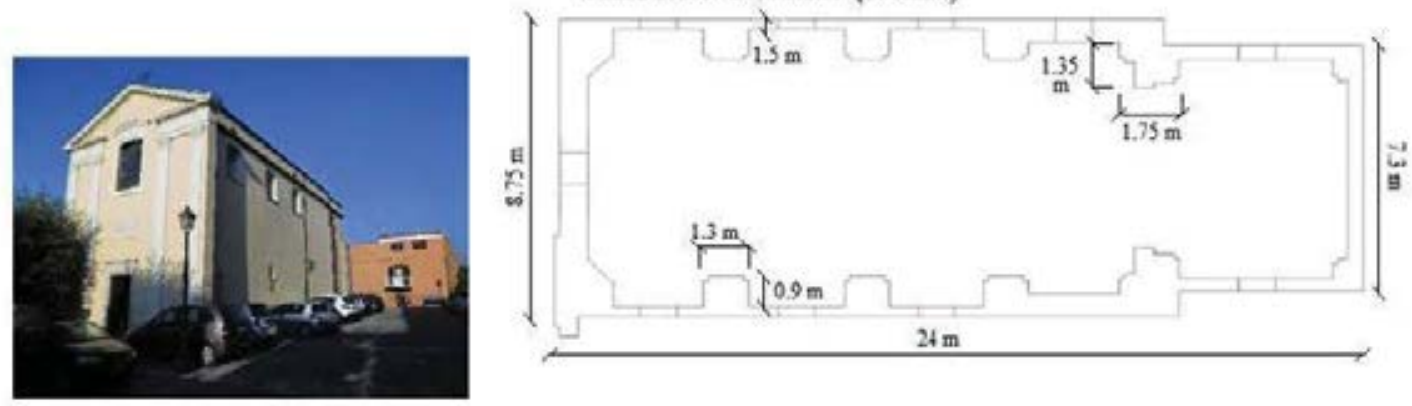

Santa Maria del Parco (Bojano, CB)
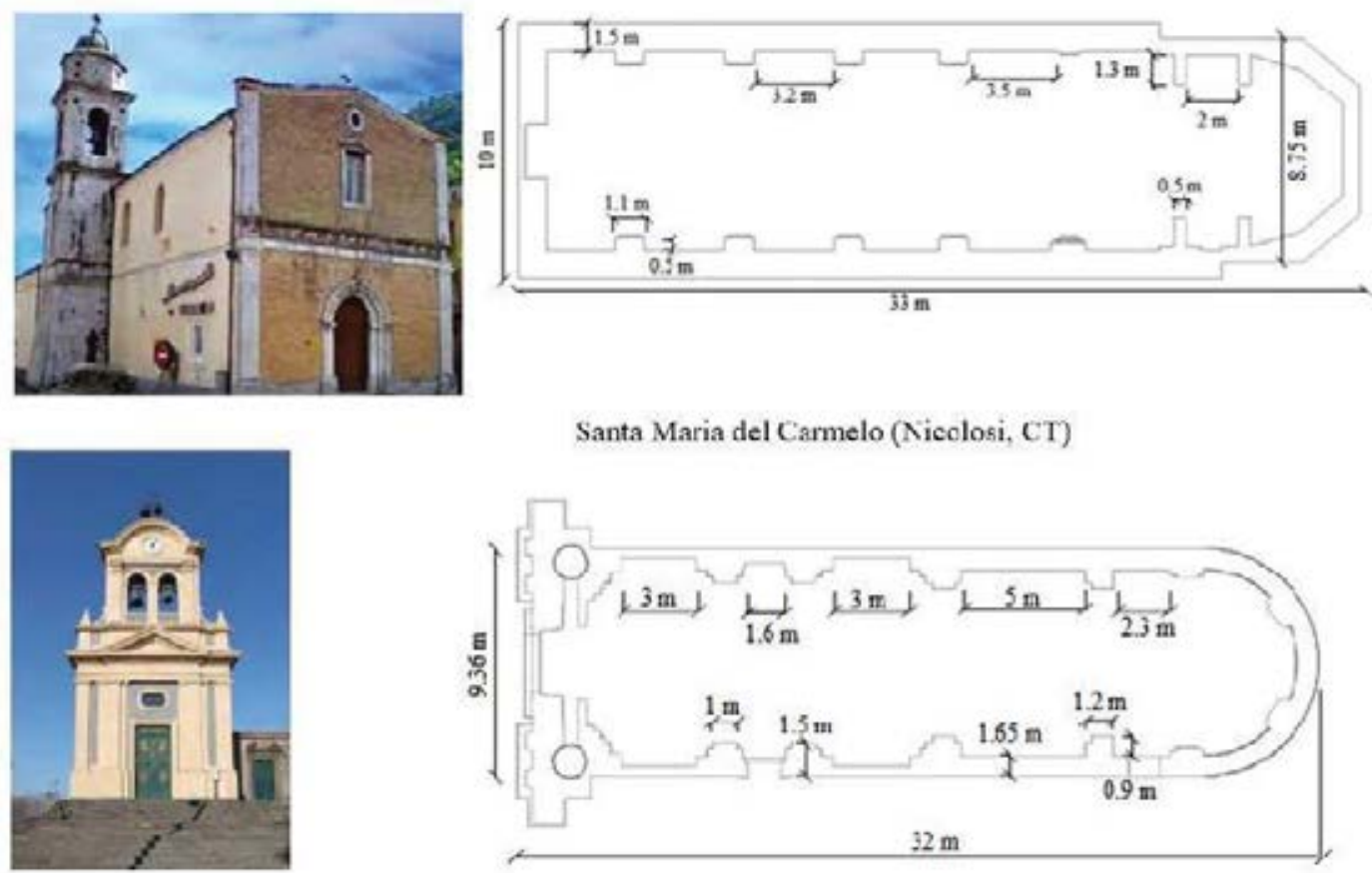

Santa Maria del Carmelo (Nicolosi, CT)
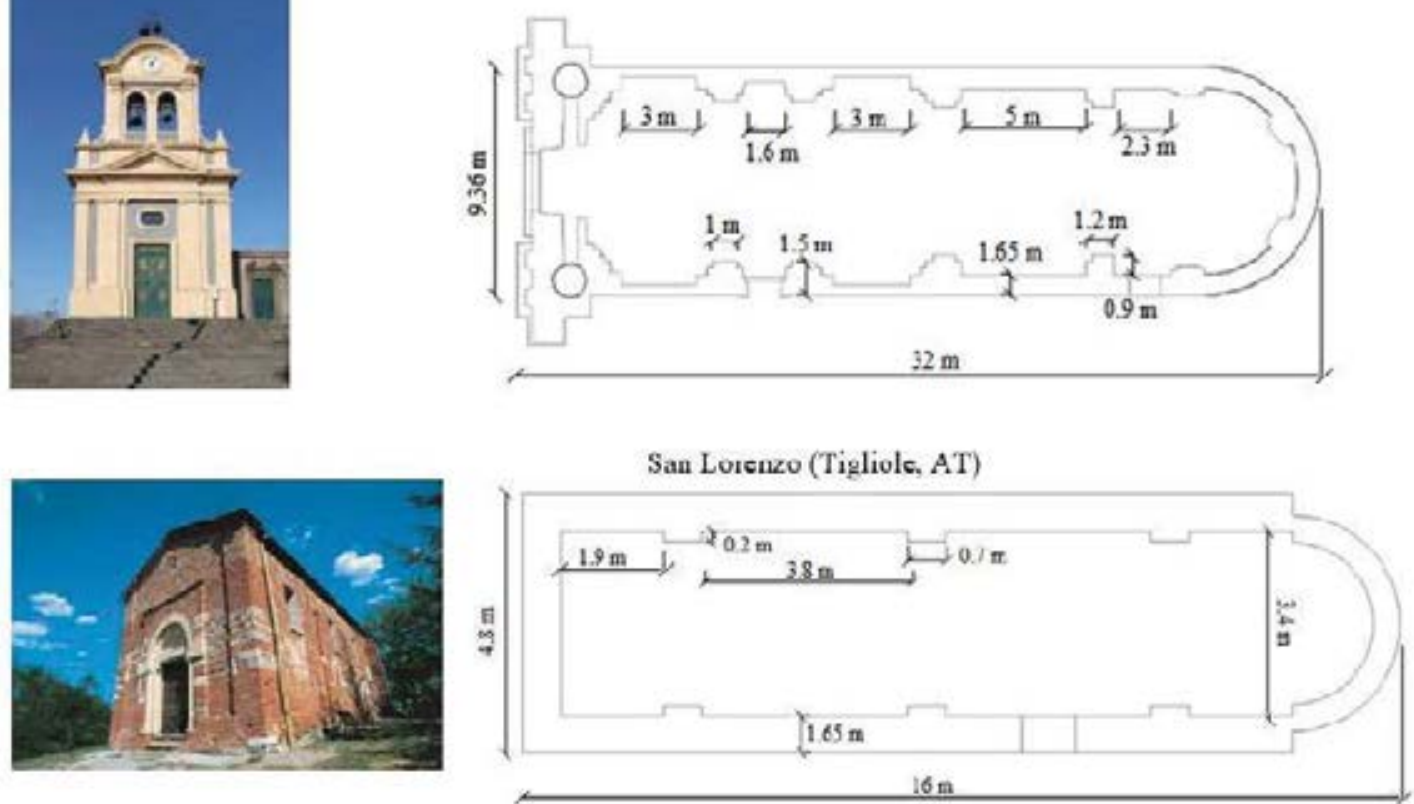

Figure 5: churches under study. 


\begin{tabular}{cccccc}
\hline configurations & $\begin{array}{c}\mathrm{t} \\
{[\mathrm{mm}]}\end{array}$ & $\begin{array}{c}\mathrm{i} \\
{[\mathrm{mm}]}\end{array}$ & $\begin{array}{c}\mathrm{k}_{\mathrm{c}} \\
{[\mathrm{N} / \mathrm{mm}]}\end{array}$ & $\mathrm{n}_{\mathrm{s}}$ & Code of the roof diaphragm configuration \\
\hline $\mathrm{a}$ & 100 & 250 & 6500 & 272 & CLT_t10_i250 \\
$\mathrm{b}$ & 80 & 125 & 6500 & 136 & CLT_t8_i125 \\
$\mathrm{c}$ & 60 & 125 & 6500 & 136 & CLT_t6_i125 \\
$\mathrm{d}$ & 60 & 250 & 6500 & 68 & CLT_t6_i250 \\
\hline
\end{tabular}

Table 2: roof diaphragm configurations.

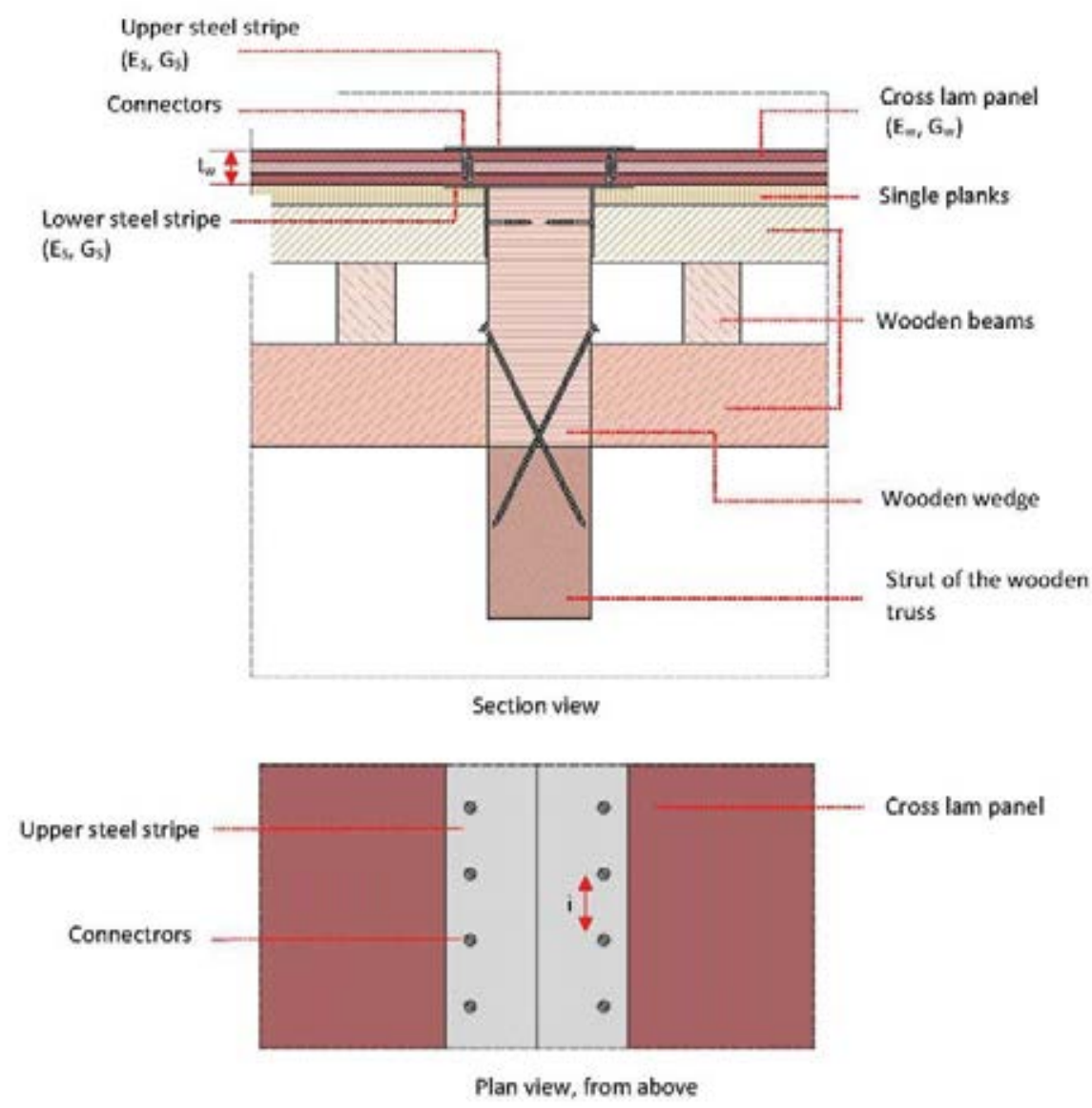

Figure 6: example of CLT panels roof-structure configuration.

Table 3 reports the values of $k_{\text {roof }}$ obtained by considering the different CLT panels roofstructure configurations for each historical church under study. As mentioned before, the seismic action implemented in the equivalent FEM through seven spectrum-compatible accelerograms detected by Rexel 3.5 software [55] considering the response spectrum of L'Aquila [56] with return period equal to 475 years [57]. 


\begin{tabular}{|c|c|c|c|}
\hline \multicolumn{4}{|c|}{ San Pietro Felizzano } \\
\hline configuration & $\begin{array}{c}\mathbf{k}_{\text {roof }} \text { between façade and ele- } \\
\text { ment } 1 \\
{[\mathrm{~N} / \mathrm{mm}]} \\
\end{array}$ & $\begin{array}{c}\text { Kroof between elements 1-2-3-4- } \\
5-6-7 \\
{[\mathrm{~N} / \mathrm{mm}]} \\
\end{array}$ & $\begin{array}{c}\text { kroof between element } 7 \text { and } \\
\text { head wall } \\
{[\mathrm{N} / \mathrm{mm}]}\end{array}$ \\
\hline CLT_t10_i250 & 103785.845 & 79185.243 & 63681.799 \\
\hline CLT_t8_i125 & 74517.507 & 57924.992 & 46760.372 \\
\hline CLT_t6_i125 & 59071.713 & 46441.943 & 37786.878 \\
\hline $\mathrm{CLT}^{-} \mathrm{t} 6$ - $\mathrm{i} 250$ & 48313.279 & 38964.366 & 31792.958 \\
\hline \multicolumn{4}{|c|}{ San Pietro Celestino } \\
\hline configuration & $\begin{array}{c}\text { between façade and element } 1 \\
\text { and elements } 2-3 \\
\text { kroof }[\mathrm{N} / \mathrm{mm}]\end{array}$ & $\begin{array}{c}\text { between elements } 1-2 \text { and el- } \\
\text { ements } 3-4 \\
\text { kroof }[\mathrm{N} / \mathrm{mm}] \\
\end{array}$ & $\begin{array}{c}\text { kroof between element } 4 \text { and } \\
\text { head wall } \\
{[\mathrm{N} / \mathrm{mm}]}\end{array}$ \\
\hline CLT_t10_i250 & 115051.513 & 98762.181 & 123290.462 \\
\hline CLT_t8_i125 & 81589.723 & 71596.946 & 83110.602 \\
\hline CLT_t6_i125 & 64852.888 & 56999.118 & 67643.925 \\
\hline CLT t6 i250 & 51976.794 & 47253.905 & 49976.935 \\
\hline \multicolumn{4}{|c|}{ Santa Maria del Parco } \\
\hline configuration & $\begin{array}{c}\text { kroof between façade and ele- } \\
\text { ment } 1 \\
{[\mathrm{~N} / \mathrm{mm}]} \\
\end{array}$ & $\begin{array}{c}\text { Kroof between elements 1-2-3-4- } \\
5-6 \\
{[\mathrm{~N} / \mathrm{mm}]} \\
\end{array}$ & $\begin{array}{c}\begin{array}{c}k_{\text {roof }} \text { between element } 6 \text { and } \\
\text { head wall } \\
{[\mathrm{N} / \mathrm{mm}]}\end{array} \\
\end{array}$ \\
\hline CLT_t10_i250 & 136821.131 & 118930.143 & 101482.358 \\
\hline CLT_t8_i125 & 97442.883 & 86152.975 & 74129.488 \\
\hline CLT_t6_i125 & 78098.949 & 68970.534 & 59572.859 \\
\hline CLT_t6_i $\mathrm{i} 250$ & 62771.455 & 56959.427 & 49797.593 \\
\hline \multicolumn{4}{|c|}{ Santa Maria del Carmelo } \\
\hline configuration & $\begin{array}{c}\text { Kroof between façade and ele- } \\
\text { ment } 1, \\
{[\mathrm{~N} / \mathbf{m m}]}\end{array}$ & $\begin{array}{c}\text { kroof between elements 1-2-3-4- } \\
5 \\
{[\mathrm{~N} / \mathrm{mm}]}\end{array}$ & $\begin{array}{c}\text { Kroof between element } 5 \text { and } \\
\text { head wall } \\
{[\mathrm{N} / \mathrm{mm}]}\end{array}$ \\
\hline CLT_t10_i250 & 130395.453 & 104761.866 & 119531.499 \\
\hline CLT_t8_i125 & 91760.781 & 76103.294 & 85715.572 \\
\hline CLT_t6_i125 & 73477.534 & 60818.342 & 68348.094 \\
\hline $\mathrm{CLT}^{-} \mathrm{t} \mathrm{C}^{-} \mathrm{i} 250$ & 58032.417 & 50501.171 & 55642.081 \\
\hline \multicolumn{4}{|c|}{ San Lorenzo } \\
\hline configuration & $\begin{array}{c}\text { kroof between façade and ele- } \\
\text { ment } 1 \text {, between elements } 1-2- \\
3 \text {, between element } 3 \text { and } \\
\text { head wall }[\mathrm{N} / \mathrm{mm}]\end{array}$ & & \\
\hline CLT_t10_i250 & 49074.997 & & \\
\hline CLT_t8_i 125 & 34984.088 & & \\
\hline CLT_t6_i125 & 26330.719 & & \\
\hline CLT_t6 i250 & 21840.971 & & \\
\hline
\end{tabular}

Table 3: $\mathrm{k}_{\text {roof }}$ values.

\section{RESULTS}

The results of the parametric analysis, considering a $\beta$ value ranging between 0.1 and 1.5 , are discussed in terms of two parameters: (i) the ratio between the drift and the height of the lateral walls (dimensionless drift) and (ii) the ratio between the base shear and the axial force on the same equivalent element (dimensionless base shear) taking into account the geometrical slenderness of the walls $\left(\lambda_{\mathrm{w}}=\mathrm{h}_{\mathrm{w}} / \mathrm{t}_{\mathrm{w}}\right)$, the geometrical slenderness of the façade $\left(\lambda_{\mathrm{f}}=\mathrm{h}_{\mathrm{f}} / \mathrm{t}_{\mathrm{f}}\right)$ and the shape factor $\left(\mathrm{S}_{\mathrm{F}}=1_{\mathrm{C}} / \mathrm{l}_{\mathrm{f}}\right)$.

The drift, the base shear and the axial force are evaluated, considering the results obtained buy the equivalent element models, as the average values of the maximum ones under the seven spectrum-compatible accelerograms.

The first step of the parametric analysis regards the choice of the optimum $\beta$ value for each church under study, considering the different roof diaphragm configurations. Figure 7 shows the results obtained from the numerical analyses where the design drift is taken equal to 5\%o of the height of the lateral walls (green line). 


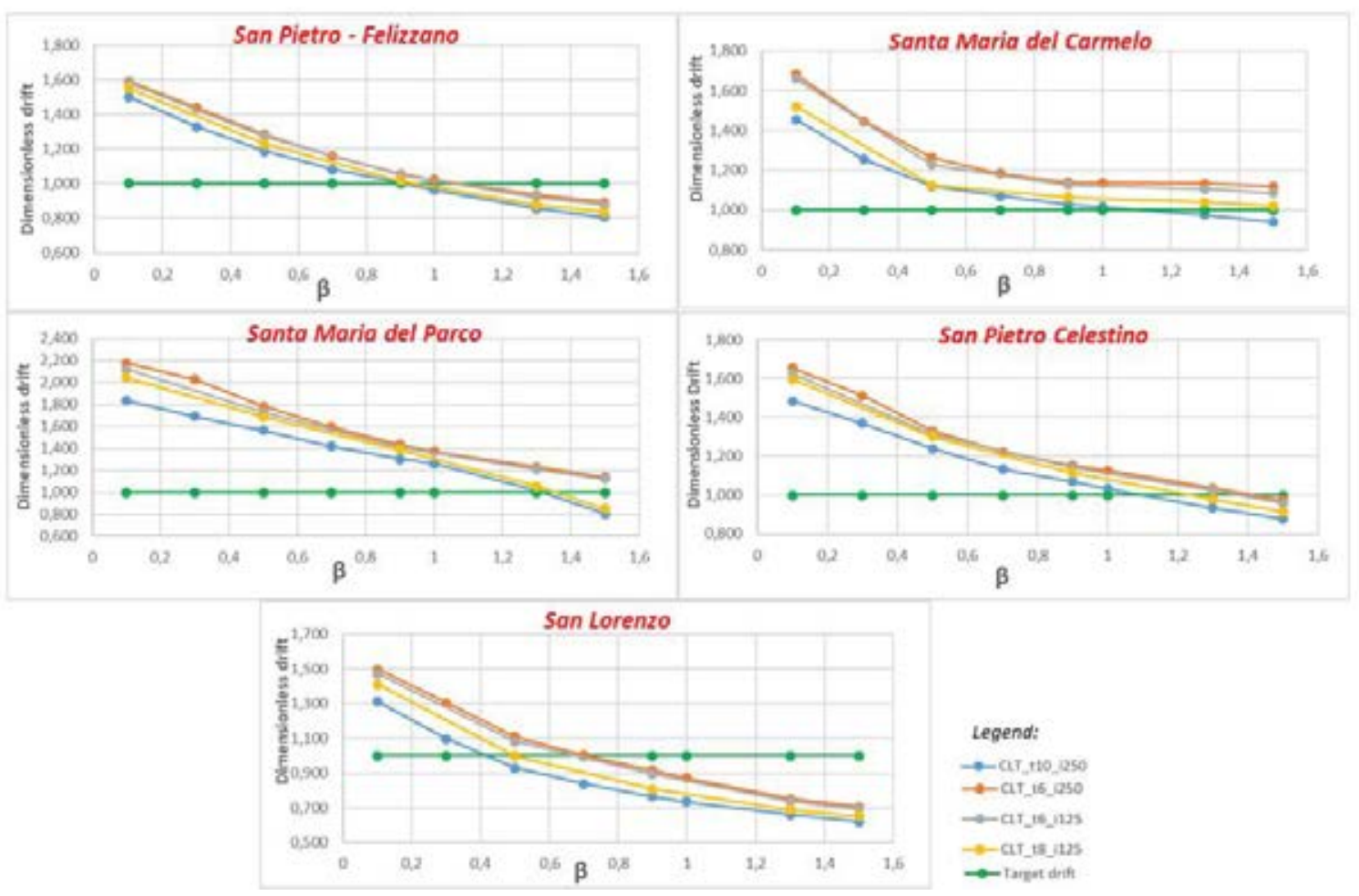

Figure 7: dimensionless drift $-\beta$ trend.

It is possible to notice that the drift decreases for high values of $\beta$ parameter because an higher energy dissipation occurs in the connections, according to as reports in Figure 3. Forthermore, the panels thickness influences the seismic response. In fact, considering the same church, when the thickness panels increases the target drift is achieved for lower value of $\beta$.

Another important aspect regards the percentage variation of the dimensionless drift $(\Delta \eta)$ for each church and the four roof diaphragm configurations by varying $\beta$ with respect to the single plank roof-configuration (tacken as zero condition). Figure 8 shows the $\Delta \eta-\beta$ trend evaluated for each church under study which are useful to understand the drift improvements as a function of $\beta$. It is possible to notice that considering the same church, the variations are more evident for panels with higher thickness. Furtermore, for the same panels thickness, the number of connections slightly influences the variations.

The third consideration regards the variations of the dimensionless base shear of the central equivalent elements and the dimensionless base shar of the façade (Figures 9 and 10). In this case, the results show that the dimensionless shear variations for the central equivalent element and for the façade are in opposite themselves. When $\beta$ increases, the base shear of the central equivalent element decreases considering that this seismic resistant element is located in the area in which the top displacement is maximum. Consequently, in the central part of the church, the drift and the base shear are in opposite themselves. Similar consideration can be made for the façade. Considering the thickness panels of the roof diaphragm, when this increases the base shear of the central equivalent element decreases. On the contrary, the façade base shear is lower for minor thickness panels. 


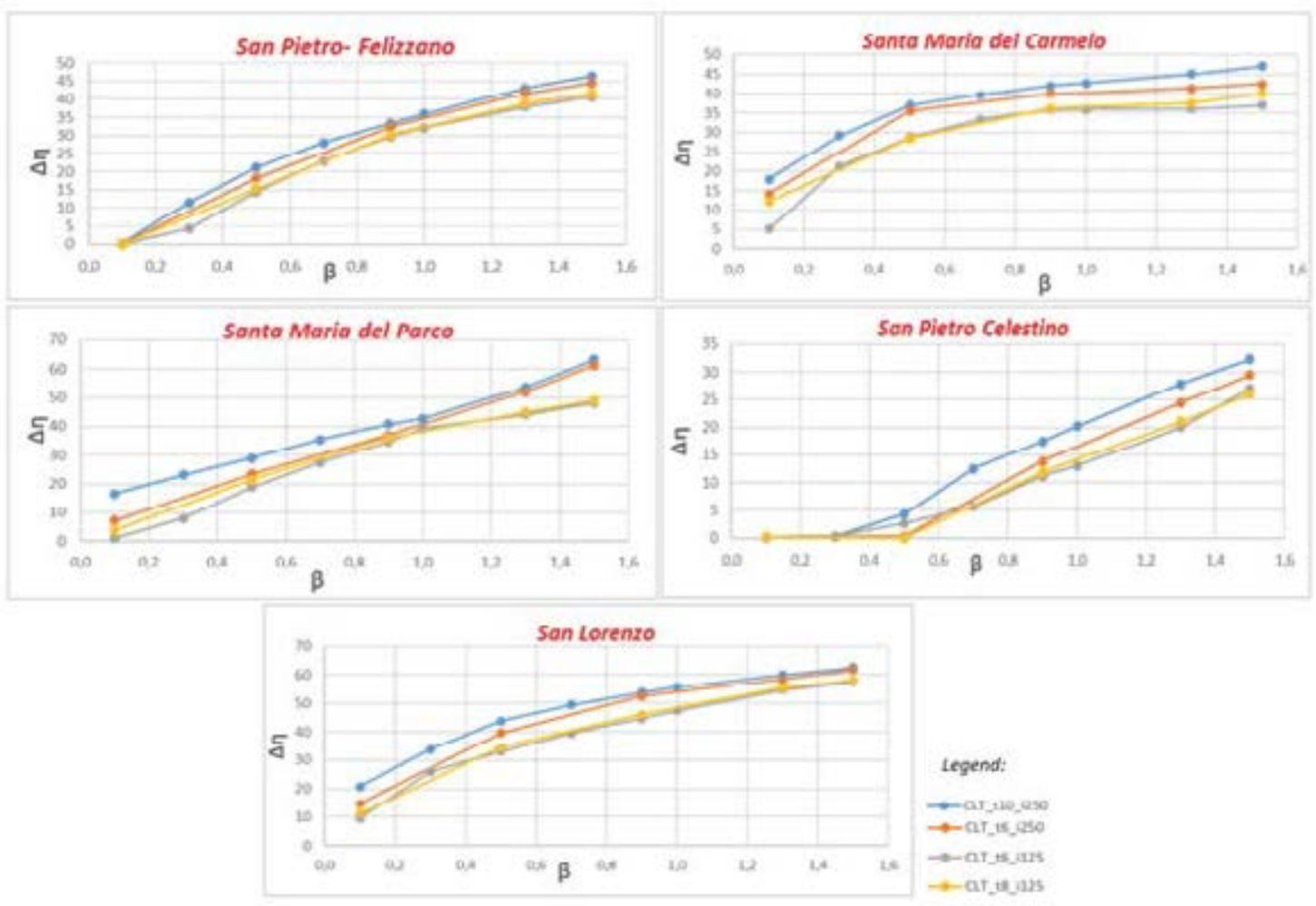

Figure 8: $\Delta \eta-\beta$ trend.
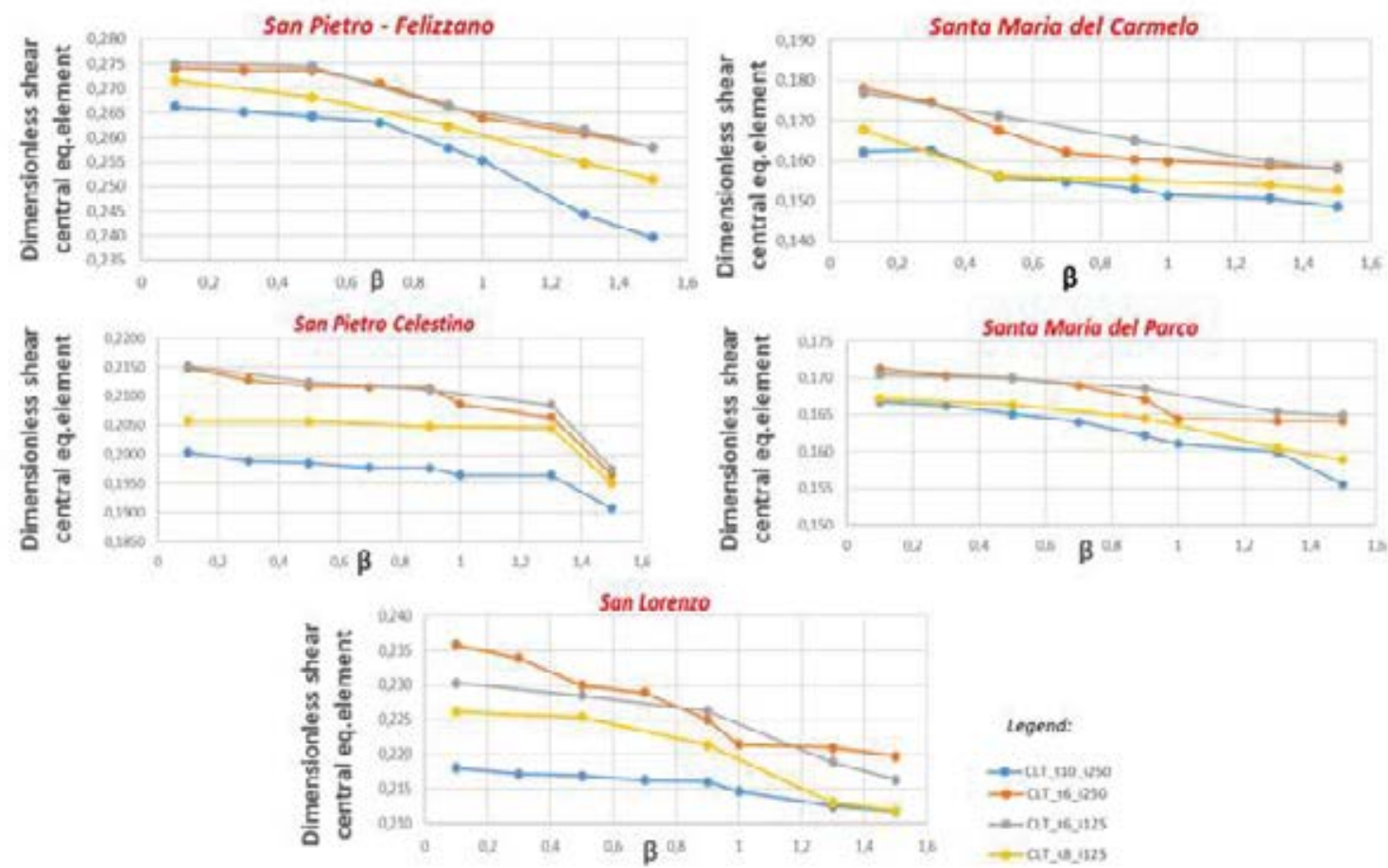

Figure 9: variation of the dimensionless base shear for the central equivalent element as a function of $\beta$. 

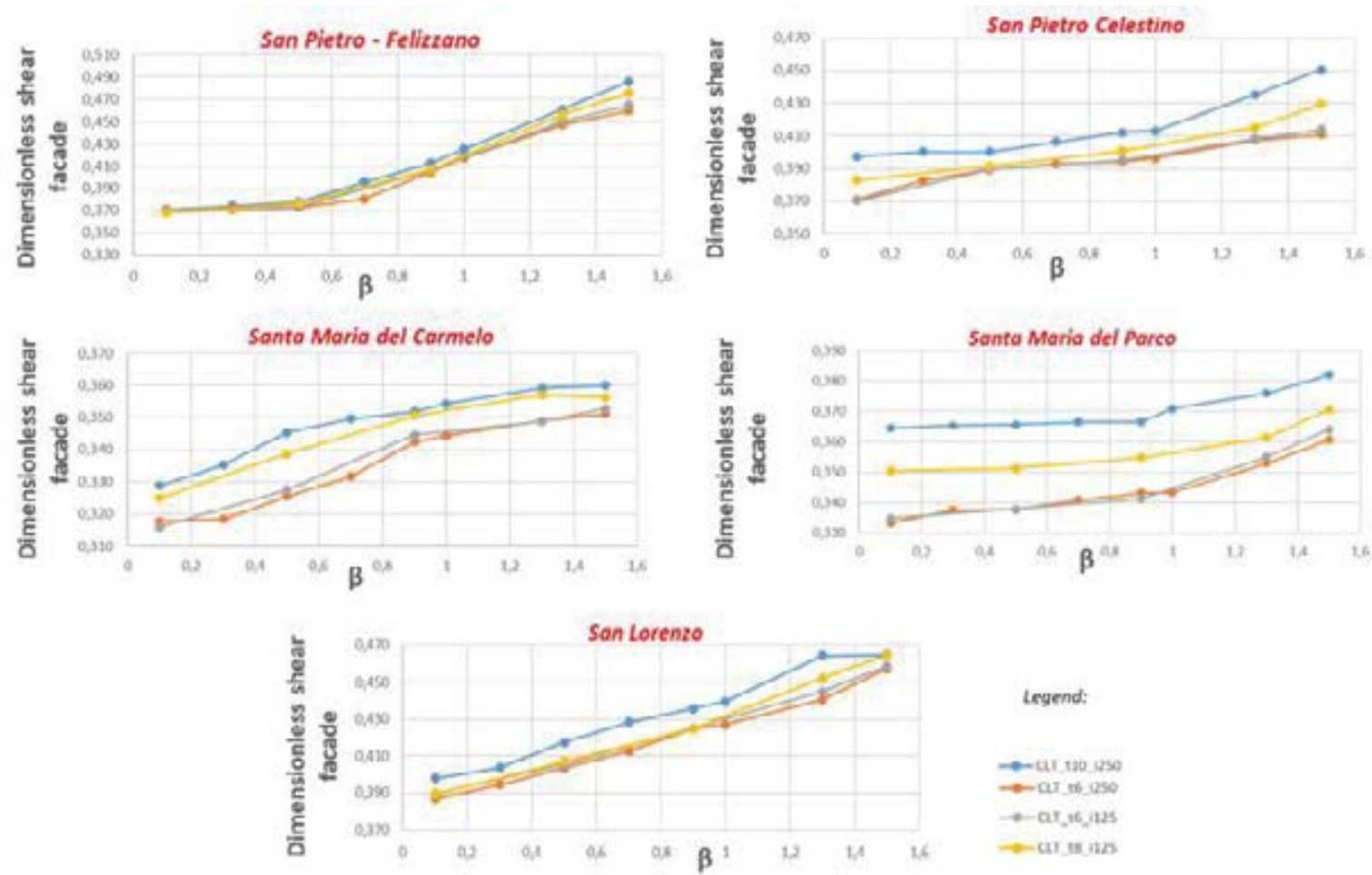

Figure 10: variation of the dimensionless base shear for the façade as a function of $\beta$.

The influence of the geometrical slenderness of the walls $\left(\lambda_{\mathrm{w}}\right)$ and the façade $\left(\lambda_{\mathrm{f}}\right)$ on the seismic response of the churches under study are analyzed considering the different roof diaphragm configurations. Figures 11 and 12 summarizes the results obtained by the numerical analyses.
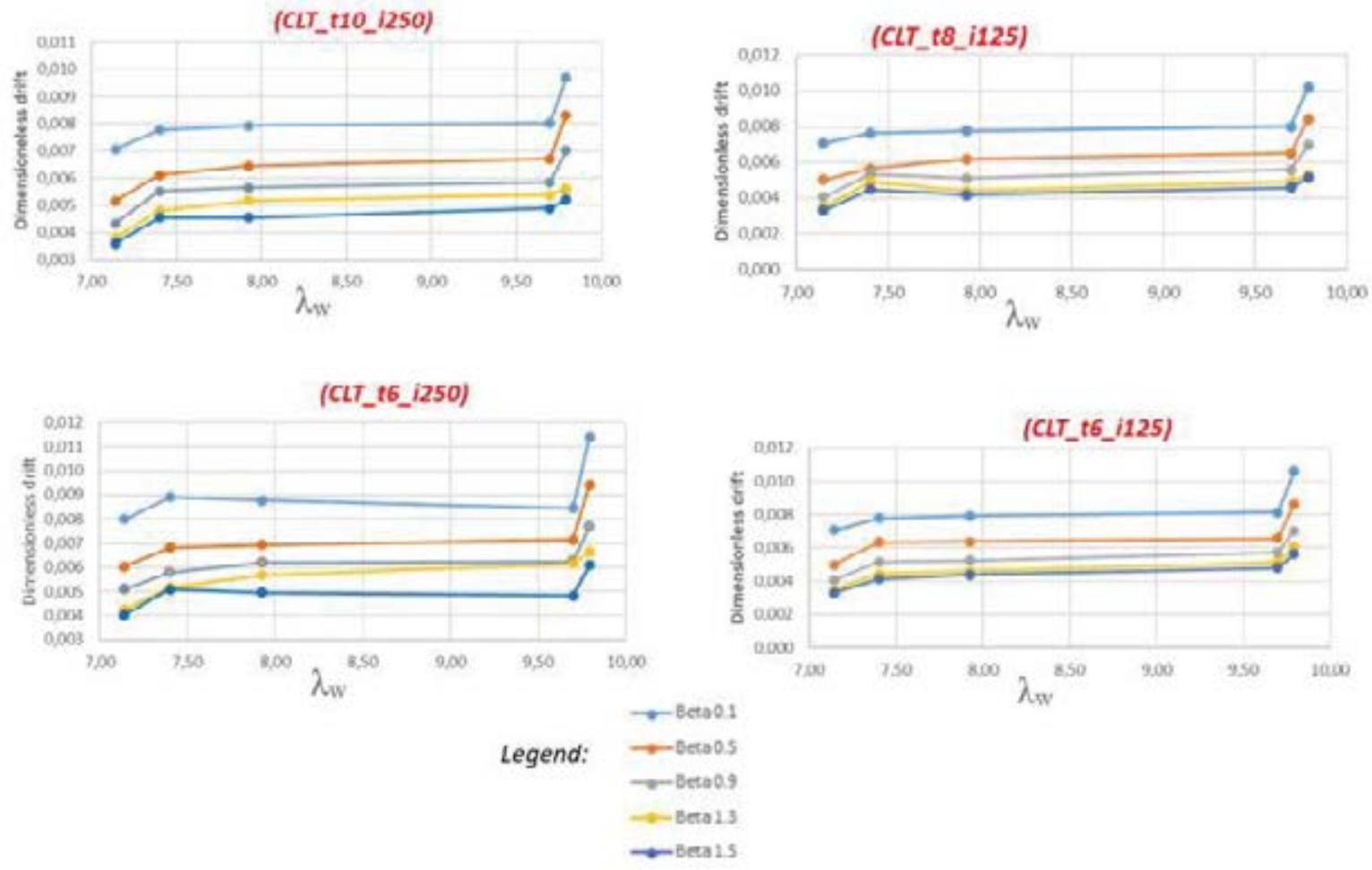

Figure 11: dimensionless drift in comparison to the geometrical slenderness of the lateral walls $\left(\lambda_{\mathrm{w}}\right)$. 

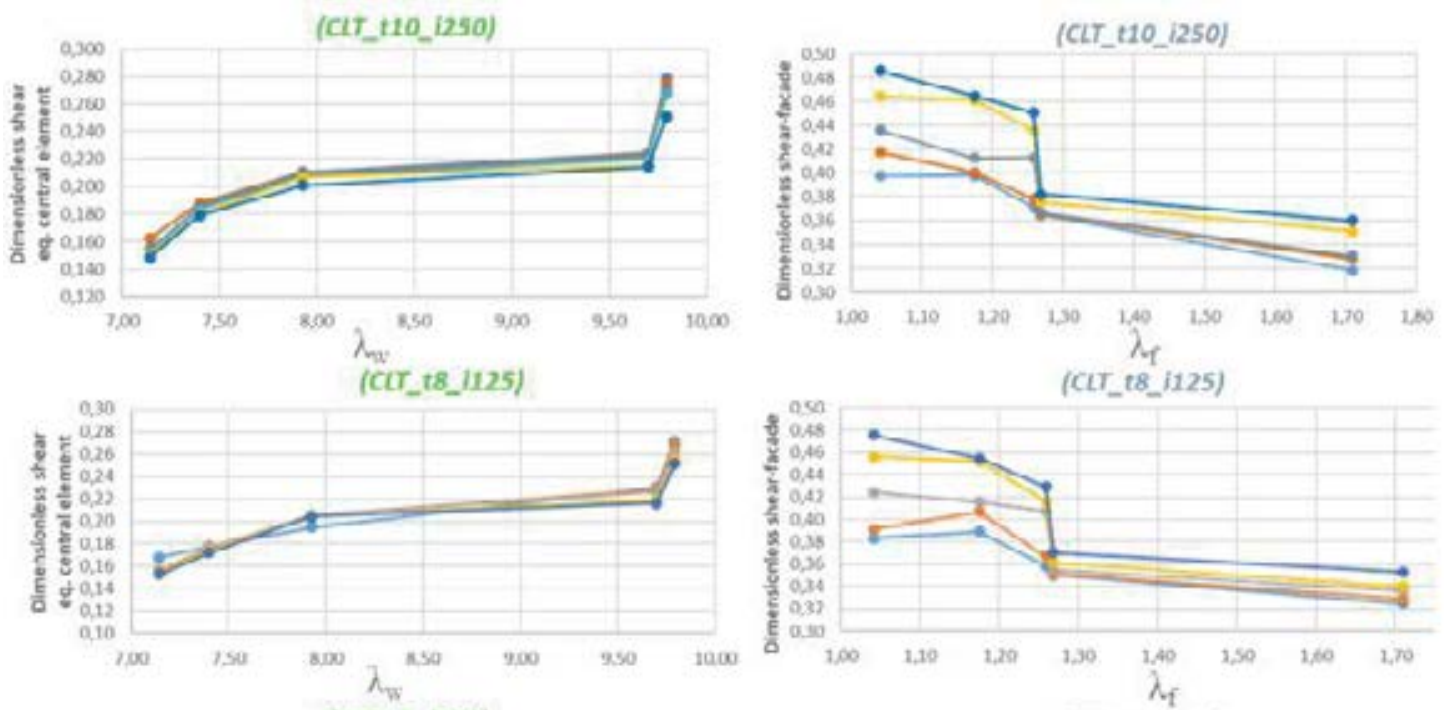

(CLI_t6_i2so)
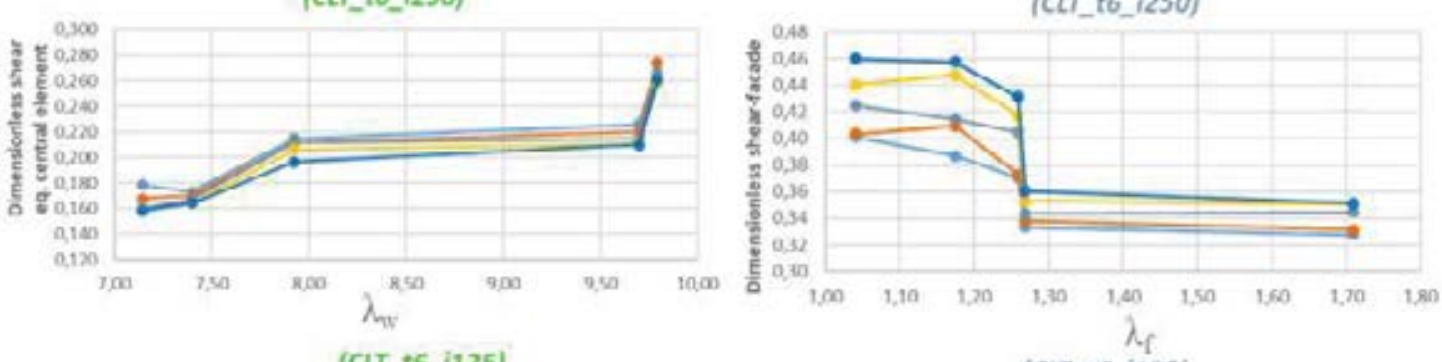

(CLI_t6_i125)
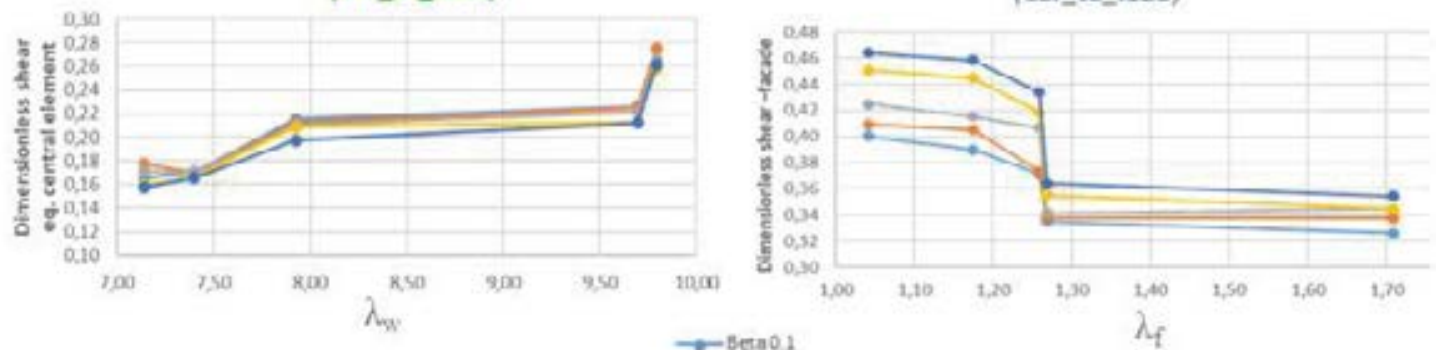

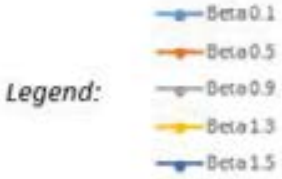

Figure 12: dimensionless base shear in comparison to the geometrical slenderness of the lateral walls $\left(\lambda_{\mathrm{w}}\right)$ and the geometrical slenderness of the façade $\left(\lambda_{\mathrm{f}}\right)$.

The results show that a slightly increases of the drift and the base shear acting on the central equivalent element occurs in correspondence to high value of lateral walls slenderness. On the contrary, the dimensionless base shear decreases when the façade slenderness increases.

Considering the trend of the drift and shear of the central equivalent element in relation to the lateral walls slenderness, abrupt variations are obtained when $9.5 \leqslant \lambda_{w} \leqslant 10$. It is important to highlight that two churches (Santa Maria del Carmelo and Santa Maria del Parco) characterized by a similar value of lateral walls slenderness were bult with different materials and, consequently, different inertia forces are involved during the seismic action. Similar consideration can be made for San Pietro Felizzano and San Pietro Celestino church, analyzing the trend of the base shear related to façade slenderness $\lambda f$. Furthermore, the shapes of the trends appear not be afflicted by the thickness of the panels or the number of the connections. 
Figures 13 and 14 summarize the results obtained considering the shape factor $\left(\mathrm{S}_{\mathrm{F}}\right)$ parameter.
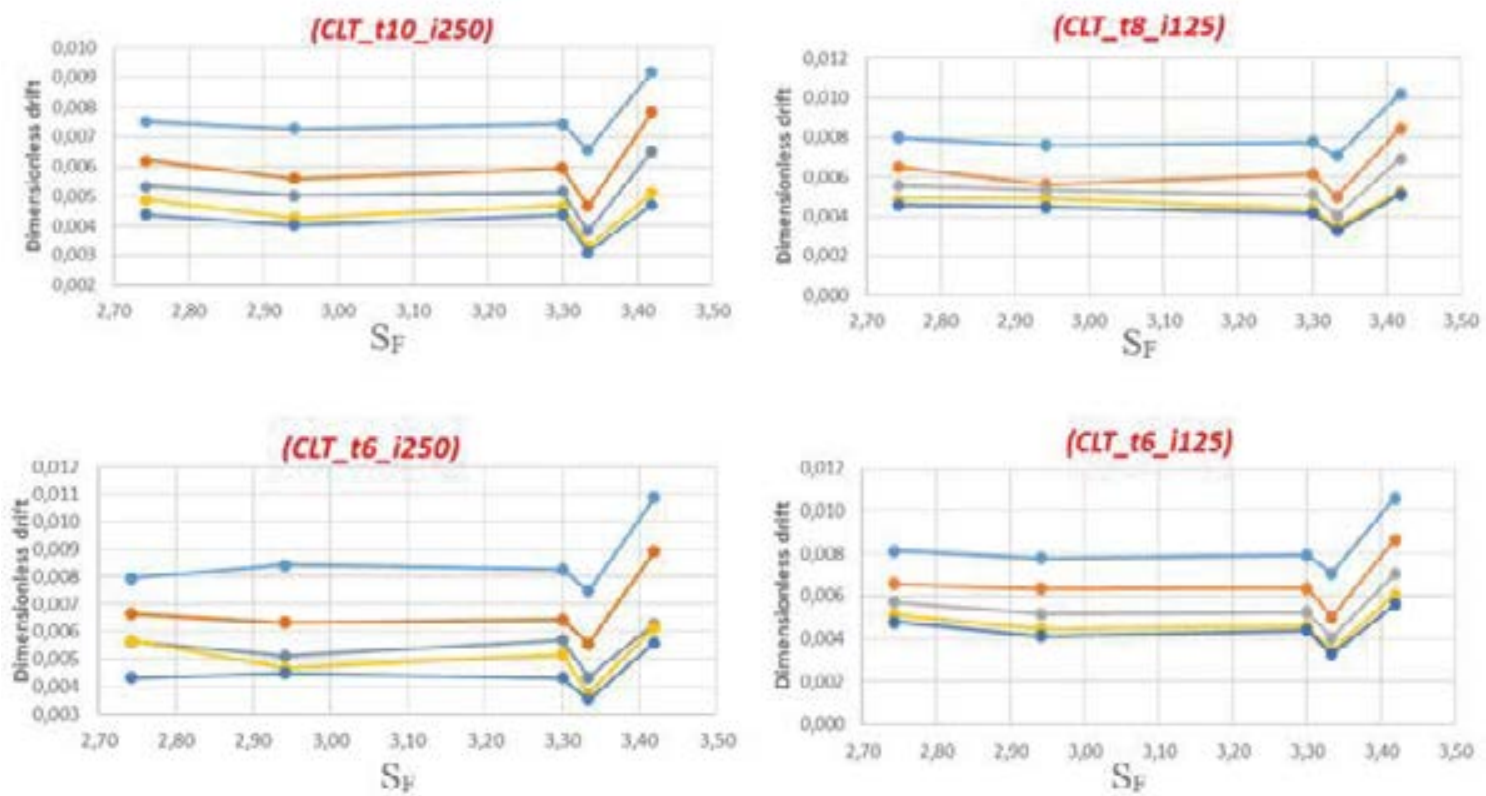

$$
\begin{aligned}
& \text { Legend: } \rightarrow \text { beta0s } \\
& \begin{array}{r}
\text { D. Beta13 } \\
\text { - Bersis }
\end{array}
\end{aligned}
$$

Figure 13: dimensionless drift in comparison to the shape factor $\mathrm{S}_{\mathrm{F}}$.

It is possible to notice that the dimensionless drift is generally constant with a slight increase for higher shape factor $\mathrm{S}_{\mathrm{F}}$. Considering the base shear acting on the central equivalent element, the trend obtained is opposite to that calculated for the façade.

Referring to the base shear of the façade, the most evident decrease occurred around $\mathrm{S}_{\mathrm{F}}=$ 3.30 for the churches Santa Maria del Parco and San Lorenzo. This fact is due to the very different geometrical characteristics that characterize the two churches (spans, total length and width). Also in this case, the shapes of the trends appear not be afflicted by the thickness of the panels or the number of the connections 

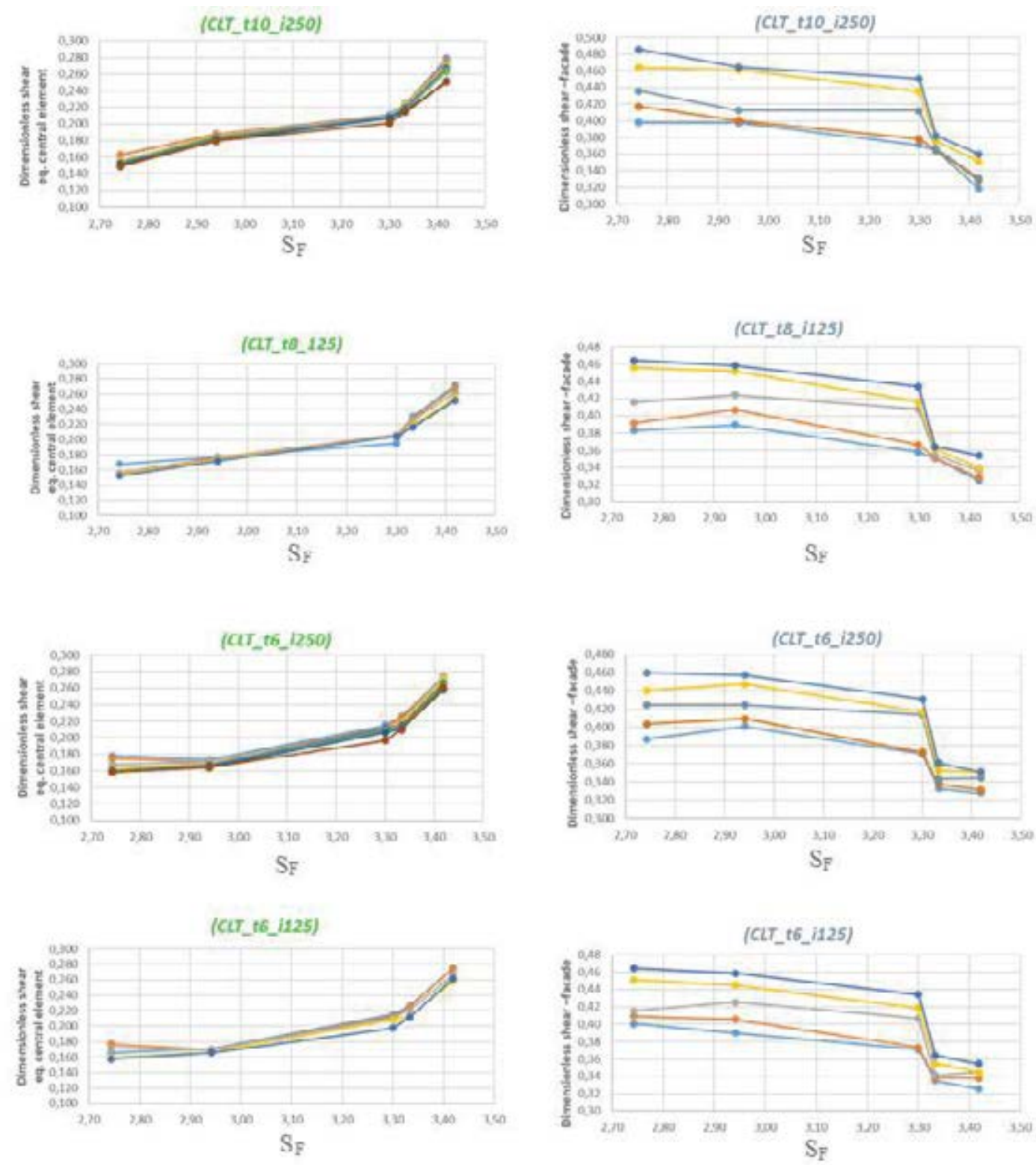

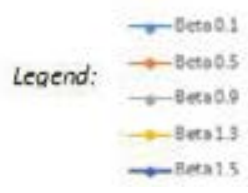

Figure 14: dimensionless base shear (central element and façade) in comparison to the shape factor $\left(\mathrm{S}_{\mathrm{F}}\right)$.

\section{CONCLUSIONS}

In this paper, the influence of the geometrical characteristics on the nave transverse response under seismic action of five historical churches, strengthen by different configurations of CLT panels roof structure, is studied through the execution of a series of non-linear dynamic analyses. The effects of the dissipative roof-diaphragm obtained by the CLT panels and connections are appreciable, especially in terms of dimensionless top displacement (drift) and dimensionless shear evaluated either at the base of the façade and the central part of the perimeter walls.

From the obtained results, the following main observations can be drawn. 
- The CLT panels roof-structure in seismic restoration of historical churches can be considered as a valid solution either for the structural benefits in the nave transverse response and the satisfaction of the conservative restoration criteria.

- The equivalent finite element model with calibrated concentrated non-linear material properties (for the masonry and the roof-diaphragm) allows to evaluate the global response of historical churches with low calculation effort.

- The damped rocking mechanism pursued by the dissipative roof-structure is mainly ruled by the variations of the hysteretic variable $\beta$ that gives a measure of the energy dissipation; the calibration of $\beta$ is preferable in the range $0 \div 1.5$ in order to limit the drift under the design drift value guaranteeing the self re-centering rocking behavior and limiting acceptable actions in the head and perimeter walls with respect to the masonry properties.

- The trends of the drift are in according to the shear: when the drift increases the façade base shear increases (while the shear at the base of the central part of the perimeter walls decreases).

- The drift and base shear variations depend more on the thickness of the CLT panels with respect to the connectors numerosity.

- The geometrical slenderness of the perimeter walls $\left(\lambda_{\mathrm{w}}\right)$ influences the nave transverse response especially beyond $\lambda_{\mathrm{w}}>9.5$ even if the seismic behavior cannot uniquely determine only by the geometrical slenderness because it is also influenced by the masonry properties (weight density and elastic modulus) and other geometrical features.

- The drift and the base shears are slightly afflicted by the shape factor.

\section{REFERENCES}

[1] N. Augenti, F. Parisi. Learning from construction failures due to the 2009 L'Aquila, Italy, earthquake. Journal of Performance of Constructed Facilities, 24(6), 2016.

[2] S. Lagomarsino. Damage assessment of churches after L'Aquila earthquake (2009). Bulletin of Earthquake Engineering, 10, 73-92, 2012.

[3] M. Zucca, P. Crespi, N. Longarini, M.A. Scamardo. The new foundation system of the Basilica di Collemaggio's transept. International Journal of Masonry Research and Innovation, 5(1), 67-84, 2020.

[4] V. Bolis, M. Preti, A. Marini, E. Giuriani. Experimental cyclic and dynamic in-plane rocking response of a masonry transverse arch typical of historical churches. Engineering Structures, 147, 285-296, 2017.

[5] E. Giuriani, A. Marini, M. Preti. Thin-folded shell for the renewal of existing wooden roofs. International Journal of Architectural Heritage, 10(6), 797-816, 2016.

[6] G. Brandonisio, E. Mele, R. Santianiello, A. De Luca. Seismic safety of basilica churches: analysis of ten case studies. $6^{\text {th }}$ International Conference of Structural Analysis of Historic Construction, Bath, United Kingdom, July 2-4, 2008.

[7] M. Valente, G. Milani. Damage survey, simplified assessment, and advanced seismic analyses of two masonry churches after the 2012 Emilia earthquake. International Journal of Architectural Heritage, 13(6), 901-924, 2019. 
[8] S. Galassi, L. Dipasquale, N. Ruggerini, G. Tempesta. Andalusian timber roof structure in Chefchaouen, Northern Morocco: construction technique and structural behavior. Journal of Architectural Engineering, 24(3), 2018.

[9] N. Longarini, P. Crespi. M. Zucca. Dissipative cross lam roof structure for seismic restoration of historical churches. $7^{\text {th }}$ Euro-American Congress on Construction Pathology, Rehabilitation Technology and Heritage Management, REHABEND 2018, Caceres, Spain, May 15-18, 2018.

[10] N. Augenti, F. Parisi. Learning from construction failures due to the 2009 L'Aquila, Italy, earthquake. Journal of Performance of Constructed Facilities, 24(6), 2016.

[11] D.F. D'Ayala, S. Paganoni. Assessment and analysis of damage in L'Aquila historic city centre after 6th April 2009. Bulletin of Earthquake Engineering, 9, 81-104, 2011.

[12] A. Penna, P. Morandi, M. Rota, C.F. Manzini, F. da Porto, G. Magenes. Performance of masonry buildings during the Emilia 2012 earthquake. Bulletin of Earthquake Engineering, 12, 2255-2273, 2014.

[13] A. Dal Cin, S. Russo. Annex and rigid diaphragm effects on the failure analysis and earthquake damages of historic churches. Engineering Failure Analysis, 59, 122-139, 2016.

[14] D. Liberatore, C. Doglioni, O. AlShawa, S. Atzori, L. Sorrentino. Effects of coseismic ground vertical motion on masonry constructions damage during the 2016 AmatriceNorcia (Central Italy) earthquakes. Soil Dynamics and Earthquake Engineering, 120, 423-435, 2019.

[15] M. Zucca, A. Franchi, P. Crespi, N. Longarini, P. Ronca. The new foundation system for the transept reconstruction of the basilica di collemaggio. $10^{\text {th }}$ International Masonry Conference, IMC 2018, Milan, Italy, July 9-11, 2018.

[16] P. Roca, R. Clemente. Studies on the origin of deformation and damage in long-span historical structures. $11^{\text {th }}$ International Conference on Fracture, ICF11, Turin, Italy, March 20-25, 2005.

[17] G. Lucibello, G. Brandonisio, E. Mele, A. De Luca. Seismic behavior of some Basilica churches after L'Aquila 2009 earthquake. Advanced Materials Research, 133-134, 801806.

[18] M. Valente. G. Barbieri, L. Biolzi. Damage assessment of three medieval churches after the 2012 Emilia earthquake. Bulletin of Earthquake Engineering, 15, 2939-2980, 2017.

[19] M. Betti, A. Vignoli. Numerical assessment of the static and seismic behaviour of the basilica of Santa Maria all'Impruneta (Italy). Construction and Building Materials, 25(12), 4308-4324, 2011.

[20] M. Betti, L. Galano, A. Vignoli. Comparative analysis on the seismic behaviour of unreinforced masonry buildings with flexible diaphragms. Engineering Structures, 6(1), 195-208, 2014.

[21] N. Gattesco, I. Boem. Numerical study on the reduction of the seismic vulnerability of historical industrial buildings with wide timber roofs. Procedia Structural Integrity, 11, 298-305, 2018.

[22] M. Zucca, P. Crespi, R. Mendoza, L. Ruggeri. Seismic assessment and retrofitting of an old masonry barrack. $8^{\text {th }}$ Euro-American Congress on Construction Pathology, Rehabil- 
itation Technology and Heritage Management, REHABEND 2020, Granada, Spain, March 24-27, 2020.

[23] N. Gattesco, L. Macorini. High reversibility technique for in-plane stiffening of wooden floors. VI International Conference on Structural Analysis of Historic Construction, SAHC08, Bath, United Kingdom, July 2-4, 2008.

[24] V. Bolis, M. Preti, A. Marini, E. Giuriani. Experimental cyclic and dynamic in-plane rocking response of a masonry transverse arch typical of historical churches. Engineering Structures, 147, 285-296, 2013.

[25] E. Giuriani, A. Marini. Wooden roof box structure for the anti-seismic strengthening of historic buildings. International Journal of Architectural Heritage, 2(3), 226-246, 2008.

[26] M.A. Parisi, M. Piazza. Seismic strengthening and seismic improvement of timber structures. Construction and Building Materials, 97, 55-66, 2015.

[27] E. Ongaretto, L. Pozza, M. Savoia. Wood-based solutions to improve quality and safety against seismic events in conservation of historical buildings. International Journal for Quality Research, 10, 17-46, 2016.

[28] I. Gavric, M. Fragiacomo, A. Ceccotti. Cyclic behaviour of typical metal connectors for cross-laminated (CLT) structures. Materials and Structures, 48, 1841-1847, 2015.

[29] N. Longarini, P. Crespi, M.A. Scamardo. Numerical approaches for cross-laminated timber roof structure optimization in seismic retrofitting of a historical masonry church. Bulletin of Earthquake Engineering, 18, 487-512, 2020.

[30] B. Roensmaens, L. Van Parys, T. Descamps. Proposal of a CLT reinforcement of old timber floors. In: Aguilar R., Torrealva D., Moreira S., Pando M.A., Ramos L.F. (eds) Structural Analysis of Historical Constructions. RILEM Bookseries, vol 18. Springer, Cham.

[31] A. Ceccotti, M. Follesa, E. Karacabeyli. 3D seismic analysis of multy-storey wood frame construction. $6^{\text {th }}$ world conference on timber engineering, Whisler resort, British Columbia, Canada, July 31-August 3, 2000.

[32] M. Follesa, I.P. Christovasilis, D. Vassallo, M. Fragiacomo, A. Ceccotti. Seismic design of multi-storey cross laminated timber buildings according to Eurocode 8. Ingegneria Sismica, 30(4), 27-53, 2013.

[33] M. Popovski, I. Gravic, J. Schneider. Performance of two-storey CLT house subjected to lateral loads. $13^{\text {th }}$ world conference on timber engineering, Quebec City, Canada, August 10-14, 2014.

[34] P. Ronca, P. Crespi, D. Bonardi, A. Palermo, S. Pampanin. High performance wooden building subjected to seismic action. International Journal for Housing Science and its Application, 161-172, 2014.

[35] A. Gubana. State-of-the-Art Report on high reversible timber to timber strengthening interventions on wooden floors. Construction and Building Materials, 97, 25-33, 2015.

[36] A. Gubana. Experimental tests on timber-to-cross lam composite section beams. $10^{\text {th }}$ world conference on timber engineering, Riva del Garda, Trento, Italy, June 20-24, 2010. 
[37] A. Gubana, M. Melotto. Experimental tests on wooden-based in-plane strengthening solutions for the seismic retrofit of traditional timber floors. Construction and Building Materials, 191, 290-299, 2018.

[38] M. Piazza, C. Baldessari, R. Tomasi. The role of in-plane floor stiffness in the seismic behaviour of traditional buildings. $14^{\text {th }}$ World Conference on Earthquake Engineering, Beijing, China, October 12-17, 2008.

[39] G. Milani, R. Shehu, M. Valente. Possibilities and limitations of innovative retrofitting for masonry churches: Advanced computations on three case studies. Construction and Building Materials, 147, 239-263, 2017.

[40] M. Valente, G. Barbieri, L. Biolzi. Seismic assessment of two masonry Baroque churches damaged by the 2012 Emilia earthquake. Engineering Failure Analysis, 79, 773-802, 2017.

[41] P. Roca, M. Cervera, G. Gariup, L. Pelà. Structural analysis of masonry historical constructions. classical and advanced approaches. Archives of Computational Methods in Engineering, 17, 299-325, 2010.

[42] S. Lagomarsino, A. Penna, A. Galasco, S. Cattari. TREMURI program: an equivalent frame model for the nonlinear seismic analysis of masonry buildings. Engineering Structures, 56, 1787-1799, 2013.

[43] G. Milani. Lesson learned after the Emilia-Romagna, Italy, 20-29 May 2012 earthquakes: a limit analysis insight on three masonry churches. Engineering Failure Analysis, 34, 761-778, 2013.

[44] P.B. Lourenco, J.G. Rots, J. Blaauwendraad. Two approaches for the analysis of masonry structures: micro and macro-modeling. Heron, 40(4), 1995.

[45] M. Preti, S. Loda, V. Bolis, S. Cominelli, A. Marini, E. Giuriani. Dissipative roof diaphragm for the seismic retrofit of listed masonry churches. Journal of Earthquake Engineering, 23(8), 1241-1261, 2019.

[46] J. Lubliner, J. Oliver, S. Oller, E. Onate. A plastic-damage model for concrete. International Journal of Solids and Structures, 25(3), 299-326, 1989.

[47] J. Lee, G.L. Fenves. Plastic-damage model for cyclic loading of concrete structures. Journal of Engineering Mechanics, 124(8), 1998.

[48] M. Preti, V. Bolis, A. Marini, E. Giuriani. Example of the benefits of a dissipative roof diaphragm in the seismic response of masonry buildings. $9^{\text {th }}$ International Conference on Structural Analysis of Historical Constructions, SAHC2014, Mexico City, Mexico, October 14-17, 2014.

[49] T.M. Ferreira, V. Romeu, A.A. Costa, H. Varum. Application of the trilinear model for the analytical study of the out-of-plane behaviour of unreinforced stone masonry walls. $9^{\text {th }}$ International Masonry Conference, Guimaraes, Portugal, July 7-9, 2014.

[50] T. Genshu, Z. Yongfeng. Seismic force modification factors for modified-Clough hysteretic model. Engineering Structures, 29, 3053-3070, 2007.

[51] G. Rinaldin, C. Amadio, M. Fragiacomo. A component approach for the hysteretic behaviour of connections in cross - laminated wooden structures. Earthquake Engineering and Structural Dynamics, 42(13), 2023-2042, 2013. 
[52] K.W. Johansen. Theory of timber connections. IABSE Publications, 9, 249-262, 1949.

[53] H.J.K.W. Larsen. Johansen's nail tests. Bygningsstatiske meddelelser, 48, 9-30, 1977.

[54] C. Sandhass, J.W.G. van de Kuilen. Strength and stiffness of timber joints with very high strength steel dowels. Engineering Structures, 131, 394-404, 2017.

[55] I. Iervolino, C. Galasso, E. Cosenza. REXEL: Computer aided record selection for code-based seismic structural analysis. Bulletin of Earthquake Engineering, 8, 339-362, 2010 .

[56] Ministerial Decree (NTC2018). Updating of Technical Codes for Constructions (in Italian). Rome: Official Gazette ${ }^{\circ} 42$ of 20/02/2018, Ordinary Supplement n`8.

[57] G. Totani, P. Monaco, F. Totani, G. Lanzo, A. Pagliaroli, S. Amoroso, D. Marchetti. Site characterization and seismic response analysis in the area of Collemaggio, L'Aquila (Italy). $5^{\text {th }}$ International Conference on Geotechnical and Geophysical Site Characterization, Gold Coast, Queensland, Australia, September 5-9, 2016. 